\title{
20. GEOCHEMISTRY OF BASALTS FROM DEEP SEA DRILLING PROJECT HOLES 556-5641
}

\author{
N. E. R. Drake, J. M. Rhodes, and L. K. Autio, Department of Geology and Geography, \\ University of Massachusetts ${ }^{2}$
}

\begin{abstract}
The nine holes (556-564) drilled during DSDP Leg 82 in a region west and southwest of the Azores Platform (Fig. 1) exhibit a wide variety of chemical compositions that indicate a complex petrogenetic history involving crystal fractionation, magma mixing, complex melting, and mantle heterogeneity. The major element chemistry of each hole except Hole 557 is typical of mid-ocean ridge basalts (MORBs), whereas the trace element and rare earth element (REE) abundances and ratios are more variable, and show that both depleted Type I and enriched Type II basalts have been erupted in the region.

Hole 556 (30-34 Ma), located near a flow line through the Azores Triple Junction, contains typically depleted basalts, whereas Hole $557(18 \mathrm{Ma})$, located near the same flow line but closer to the Azores Platform, is a highly enriched FeTi basalt, indicating that the Azores hot-spot anomaly has existed in its present configuration for at least $18 \mathrm{Ma}$, but less than 30-34 Ma.

Hole 558 (34-37 Ma), located near a flow line through the FAMOUS and Leg 37 sites, includes both Type I and II basalts. Although the differences in $\mathrm{Zr} / \mathrm{Nb}$ and light REE/heavy REE ratios imply different mantle sources, the (La/ $\mathrm{Ce})_{\mathrm{ch}}(>1)$ and $\mathrm{Nd}$ isotopic ratios are almost the same, suggesting that the complex melting and pervasive, small-scale mantle heterogeneity may account for the variations in trace element and REE ratios observed in Hole 558 (and FAMOUS sites).

Farther south, Hole 559 (34-37 Ma), contains enriched Type II basalts, whereas Hole 561 (14-17 Ma), located further east near the same flow line, contains Type I and II basalts. In this case, the $(\mathrm{La} / \mathrm{Ce})_{\mathrm{ch}}$ and $\mathrm{Nd}$ isotopic ratios are different, indicating two distinct mantle sources. Again, the existence along the same flow line of two holes exhibiting such different chemistry suggests that mantle heterogeneity may exist on a more pervasive and transient smaller scale. (Hole 560 was not sampled for this study because the single basalt clast recovered was used for shipboard analysis.)

All of the remaining three holes $(562,563,564)$, located along a flow line about $100 \mathrm{~km}$ south of the Hayes Fracture Zone $\left(33^{\circ} \mathrm{N}\right)$, contain only depleted Type I basalts.

The contrast in chemical compositions suggests that the Hayes Fracture Zone may act as a "domain" boundary between an area of fairly homogeneous, depleted Type I basalts to the south (Holes 562-564) and a region of complex, highly variable basalts to the north near the Azores hot-spot anomaly (Holes 556-561).
\end{abstract}

\section{INTRODUCTION}

During DSDP Leg 82, nine holes (556-564) were drilled near several spreading flow lines perpendicular to the Mid-Atlantic Ridge in a region west and southwest of the Azores Platform (Fig. 1). The northern flow lines are on either side of the Pico Fracture Zone and pass through the Azores Triple Junction (Holes 556 and 557) and the FAMOUS and Leg 37 sites (Hole 558). The southern flow lines straddle the Hayes Fracture Zone (Holes 559-561 and 562-564) $650 \mathrm{~km}$ south of the Azores Triple Junction. Drilling perpendicular to the ridge axis in crust aged 14-18 Ma (Anomalies 5-6) and 30-37 Ma (Anomalies 12-13) provided an opportunity to examine geochemical changes with time at a particular ridge segment. Figure 1 shows the position of the drill sites and summarizes the geochemical characteristics of the basalts from each hole. No analyses from Hole 560 are included because only one basalt clast was recovered, which was used for shipboard analysis. Further details on locations and recovery are given in the site chapters of this volume.

\footnotetext{
${ }^{1}$ Bougault, H., Cande, S. C., et al., Init. Repts. DSDP, 82: Washington (U.S. Govt. Printing Office).

2 Address: Department of Geology and Geography, University of Massachusetts, Amherst, Massachusetts 01003.
}

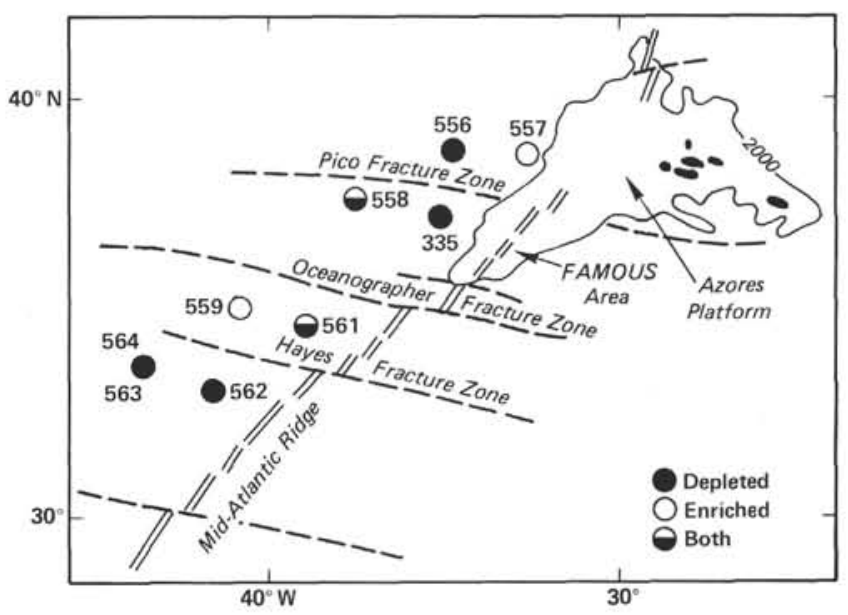

Figure 1. Location and chemical characteristics of basalts sampled on DSDP Leg 82.

The task of this study was to examine geochemical variations over the past $35 \mathrm{Ma}$ in order to evaluate the roles played by crystal fractionation, magma mixing, complex melting, and large-scale or small-scale mantle heterogeneity in the petrogenesis of Leg 82 basaltic magmas. Such information is fundamental to a broader understanding of the composition and evolution of the oceanic mantle and crust. 
The 96 samples collected for this study were analyzed for major and trace elemental abundances by X-ray fluorescence (XRF) techniques (Appendixes A and B). Seven samples were selected for rare earth element (REE) analysis by instrumental neutron activation analysis (INAA) (Table 1). The chemical abundances and ratios were used to determine the chemical groups that in turn were used to evaluate the complex processes involved in basalt petrogenesis in the Leg 82 area. The geochemical data were also used to examine the important question of whether the Azores hot-spot anomaly consists of a single mantle plume (Schilling, 1975) or represents sampling of pervasive, small-scale mantle veining (Hanson, 1977; Zindler et al., 1979). The role of fracture zones (in this case, the Hayes Fracture Zone at $33^{\circ} \mathrm{N}$ ) as possible domain boundaries between regions of mantle with different chemical signatures was also considered (Melson and O'Hearn, 1979; Bougault and Treuil, 1980).

Throughout the text, tables, figures, and appendixes we have used our own simplified sample numbering system. The first part of the number refers to the hole number (556-564) and the second part represents the samples in order of increasing depth within basement (i.e., the number 1 refers to the sample nearest the top of each hole). The DSDP designation for each sample can be found in the second to fourth rows at the top of Appendix A, Tables 1-7, which list all of the major and trace element abundances for each sample by hole number in order of increasing depth within basement.

\section{METHODS}

Samples were crushed in a tungsten carbide shatterbox at the Ronald B. Gilmore X-Ray Facility in the Department of Geology and Geography at the University of Massachusetts in Amherst. The major element data were obtained by XRF on fused glass disks, prepared by fusing the sample with a lanthanum-bearing lithium tetraborate flux (Norrish and Hutton, 1969). The trace elements (Rb, Sr, Y, Ga, Zr, $\mathrm{Nb}, \mathrm{Zn}, \mathrm{Ni}, \mathrm{Cr}$, and $\mathrm{V}$ ) were determined by $\mathrm{XRF}$ analysis on pressed powder pellets. Corrections were made for nonlinear backgrounds, tube contamination, and interelement interferences (Norrish and Chappell, 1967). Corrections for matrix effects were based on a modification of the Compton scattering method (Reynolds, 1967). Additional trace element and REE data ( $\mathrm{La}, \mathrm{Ce}, \mathrm{Nd}, \mathrm{Sm}, \mathrm{Eu}, \mathrm{Yb}, \mathrm{Lu}, \mathrm{Hf}, \mathrm{Sc}$ ) (Table 1) were obtained by INAA in Fred Frey's laboratory at the Cen- ter for Geoalchemy in the Department of Earth and Planetary sciences at the Massachusetts Institute of Technology, by the methods of Jacobs and others (1977).

Average values for BCR-1 analyzed as an unknown by XRF are given in Table 2 with one standard deviation. Each element was analyzed twice for each sample. Error values labeled Leg 82 in Table 2 are based on these replicate analyses and apply directly to the Leg 82 basalts under the given operating conditions. The values were calculated using the formula:

$$
s=\sqrt{\Sigma(x-\bar{x})^{2} /(n-1)},
$$

where $x$ and $\bar{x}$ are observation and mean for replicate analyses of the same element in a single sample and $n$ is the number of samples analyzed.

$\mathrm{Mg}^{\prime}$-values were calculated as molecular $\mathrm{Mg} /\left(\mathrm{Mg}+\mathrm{Fe}^{2+}\right)$, where molecular $\mathrm{Fe}$ has been proportioned as $\mathrm{Fe}^{3+} /\left(\mathrm{Fe}^{2+}+\mathrm{Fe}^{3+}\right)=0.1$ (Basaltic Volcanism Study Project, 1981). $\mathrm{Fe}_{2} \mathrm{O}_{3}{ }^{*}$ and $\mathrm{FeO}^{*}$ refer to total $\mathrm{Fe}$ expressed as $\mathrm{Fe}^{3+}$ or $\mathrm{Fe}^{2+}$, respectively. Major elements are expressed as weight percent (wt.\%) and trace elements in parts per million (ppm).

\section{BASALT CHEMISTRY}

\section{Hole 556}

Hole 556 is located near Anomaly 12 (30-34 Ma) about $80 \mathrm{~km}$ north of the Pico Fracture Zone on a flow line extending through the Azores Triple Junction (Fig. 1). The 16 basalt samples analyzed from $177 \mathrm{~m}$ of basement may be classified as two distinct, but stratigraphically interlayered basalt types. Group I is the more primitive of the two, with moderately high $\mathrm{MgO}$ (7.4 wt.\%) and $\mathrm{CaO}\left(13.3\right.$ wt. \%) contents, $\mathrm{Mg}^{\prime}$-values (0.66), and $\mathrm{CaO} / \mathrm{Al}_{2} \mathrm{O}_{3}$ ratios (0.83) (Appendix A, Table 1; Appendix B, Table 1; Figs. 2-4). Ni (100 ppm) and $\mathrm{Cr}(340$ ppm) contents are the lowest of all Leg 82 basalts and the $\mathrm{Sr}(99 \mathrm{ppm})$ contents are relatively low also (Figs. 5, 6). Incompatible element abundances, $\mathrm{TiO}_{2}$ (1 wt.\%), $\mathrm{Zr}(48 \mathrm{ppm}), \mathrm{Y}(22 \mathrm{ppm})$, and $\mathrm{Nb}(1.8 \mathrm{ppm})$ as well as $\mathrm{Zr} / \mathrm{Y}$ ratios (2.5) (Fig. 7), are low relative to other oceanfloor basalts (Melson et al., 1977; Basaltic Volcanism Study Project, 1981).

Within Group I, two subgroups can be recognized; IA $(556-1,2,7,8,9,11,13-16)$ and IB $(556-10,12,17)$. Subgroup IA has lower Ni ( 99 versus $110 \mathrm{ppm}$ ) contents, $\mathrm{Mg}^{\prime}$-values (0.64 versus 0.67 ), and $\mathrm{CaO} / \mathrm{Al}_{2} \mathrm{O}_{3}$ ratios

Table 1. Rare earth element and trace element abundances (ppm) in selected Leg 82 basalts.

\begin{tabular}{|c|c|c|c|c|c|c|c|c|c|c|}
\hline Univ. Mass, sample number & $558-1$ & $558-2$ & $558-7$ & $558-13$ & $561-2$ & $561-6$ & $563-2$ & ML-76 & NB-STD & $\mathrm{N}$ \\
\hline Hole & 558 & 558 & 558 & 558 & 561 & & & & & \\
\hline Core-Section & $27-3$ & $28-1$ & $33-2$ & $38-1$ & $1-1$ & $2-2$ & $24-1$ & & & \\
\hline (interval in $\mathrm{cm}$ ) & $112-114$ & $55-58$ & $144-147$ & $97-99$ & $4-9$ & $82-84$ & $22-25$ & & & \\
\hline Sub-bottom depth (m) & 409.13 & 415.07 & 462.46 & 505.48 & 411.57 & 416.83 & 366.24 & & & \\
\hline $\mathrm{La}$ & 6.42 & 3.06 & 9.79 & 5.33 & 13.99 & 2.87 & 1.93 & 9.67 & 10.73 & 0.33 \\
\hline $\mathrm{Ce}$ & 14.7 & 7.5 & 19.4 & 13.0 & 26.8 & 8.2 & 5.6 & 23.2 & 27.7 & 0.88 \\
\hline $\mathrm{Nd}$ & 12.0 & 9.7 & 17.1 & 10.7 & 20.0 & 9.8 & 7.8 & 26.8 & 16.8 & 0.60 \\
\hline $\mathrm{Sm}$ & 2.81 & 2.63 & 3.09 & 2.12 & 3.68 & 3.02 & 2.08 & 4.79 & 3.72 & 0.181 \\
\hline $\mathrm{Eu}$ & 1.01 & 0.96 & 1.10 & 0.79 & 1.22 & 1.41 & 0.82 & 1.70 & 1.21 & 0.069 \\
\hline $\mathrm{Yb}$ & 2.42 & 3.06 & 2.36 & 2.12 & 2.88 & 3.78 & 2.67 & 2.15 & 2.32 & 0.20 \\
\hline Lu & 0.38 & 0.43 & 0.34 & 0.34 & 0.44 & 0.55 & 0.41 & 0.30 & 0.48 & 0.034 \\
\hline $\mathrm{Sc}$ & 34.1 & 40.1 & 36.1 & 35.9 & 36.9 & 42.5 & 41.4 & 30.5 & 9.9 & \\
\hline $\mathrm{Hf}$ & 1.97 & 1.70 & 2.01 & 1.50 & 2.20 & 2.10 & 1.37 & 3.43 & 5.76 & \\
\hline$(\mathrm{La} / \mathrm{Ce})_{\mathrm{ch}}$ & 1.16 & 1.09 & 1.35 & 1.09 & 1.39 & 0.93 & 0.92 & 1.11 & 1.02 & \\
\hline$(\mathrm{La} / \mathrm{Sm})$ & 1.25 & 0.63 & 1.74 & 1.38 & 2.09 & 0.52 & 0.51 & 1.11 & 1.58 & \\
\hline$(\mathrm{La} / \mathrm{Yb})_{\mathrm{ch}}$ & 1.61 & 0.61 & 2.51 & 1.52 & 2.94 & 0.46 & 0.49 & 2.73 & 2.80 & \\
\hline
\end{tabular}

Note: $\mathrm{ch}=$ chondrite-normalized ratios. ML-76 = Mauna Loa sample used as University of Massachusetts internal standard. NB-STD $=$ M.I.T. internal standard. $\mathrm{N}$ refers to values used to normalize REE abundances to chondrites. 
Table 2. Precision of whole-rock basalt chemistry analyses.

\begin{tabular}{|c|c|c|}
\hline Elements & BCR-1 & Leg 82 error \\
\hline \multicolumn{3}{|c|}{ Major element (wt.\%) } \\
\hline $\mathrm{SiO}_{2}$ & $54.51(0.17)$ & $(0.07)$ \\
\hline $\mathrm{TiO}_{2}$ & $2.25(0.01)$ & $(0.03)$ \\
\hline $\mathrm{Al}_{2} \mathrm{O}_{3}$ & $13.52(0.10)$ & $(0.05)$ \\
\hline $\mathrm{Fe}_{2} \mathrm{O}_{3}{ }^{*}$ & $13.36(0.04)$ & $(0.04)$ \\
\hline $\mathrm{MnO}$ & $0.19(0.01)$ & $(0.01)$ \\
\hline $\mathrm{MgO}$ & $3.33(0.04)$ & $(0.04)$ \\
\hline $\mathrm{CaO}$ & $6.93(0.03)$ & $(0.19)$ \\
\hline $\mathrm{Na}_{2} \mathrm{O}$ & $3.30(0.28)$ & $(0.18)$ \\
\hline $\mathrm{K}_{2} \mathrm{O}$ & $1.70(0.01)$ & $(0.01)$ \\
\hline $\mathrm{P}_{2} \mathrm{O}_{5}$ & $0.38(0.01)$ & $(0.001)$ \\
\hline
\end{tabular}

Trace element (ppm)

$\begin{array}{lcl}\mathrm{Rb} & 46.4(0.3) & (0.20) \\ \mathrm{Sr} & 326(1) & (0.58) \\ \mathrm{Y} & 33.5(0.3) & (0.28) \\ \mathrm{Ga} & 22.2(0.6) & (1.49) \\ \mathrm{Zr} & 194.5(1.8) & (0.55) \\ \mathrm{Nb} & 12.5(0.4) & (0.46) \\ \mathrm{Zn} & 128(2) & (0.56) \\ \mathrm{Ni} & 22.8(9.7) & (6.60) \\ \mathrm{Cr} & 5.7(1.4) & (1.28) \\ \mathrm{V} & 360(4) & (2.39)\end{array}$

Note: BCR-1 is a U.S.G.S. standard analyzed with every X-ray fluorescence run. Mean and 1 standard deviation (expressed in wt. \% or ppm) are given. The column labeled Leg 82 error refers to the precision of analysis at the Leg 82 concentration (see text) and is given as 1 standard deviation.

( 0.83 versus 0.87 ), along with higher incompatible element abundances, $\mathrm{TiO}_{2}$ (1.02 versus 0.86 wt. \%), $\mathrm{Zr}$ (58 versus $48 \mathrm{ppm}$ ), and Y (23 versus $20 \mathrm{ppm}$ ), than Subgroup IB. However, the $\mathrm{Sr}(99$ versus $100 \mathrm{ppm})$ content is the same for both subgroups (Fig. 6). The three samples from Subgroup IB and one sample from Subgroup IA (556-7) are unusually high in $\mathrm{CaO}$ (14 wt.\%) (Fig. 3) for ocean-floor basalts (Melson et al., 1977; Basaltic Volcanism Study Project, 1981). These samples have few or no phenocrysts and no obvious carbonate veining or alteration.

Group II, consisting of four samples (556-3 through 556-6) has lower $\mathrm{MgO}$ (6.75 wt.\%), $\mathrm{CaO}$ (11.7 wt.\%), $\mathrm{Ni}(89 \mathrm{ppm})$, and $\mathrm{Cr}(250 \mathrm{ppm})$ contents, $\mathrm{Mg}^{\prime}$-values $(0.58)$, and $\mathrm{CaO} / \mathrm{Al}_{2} \mathrm{O}_{3}$ ratios $(0.70)$, along with greater $\mathrm{Zr} / \mathrm{Y}$ ratios (2.9) and incompatible element abundances$\mathrm{TiO}_{2}$ (1.45 wt.\%), $\mathrm{Zr}$ (90 ppm), Nb (2.5 ppm), and $\mathrm{Y}$ (30 ppm)-than Group I. Group II also contains 100 ppm of Sr, the same amount as in Group I (Fig. 6).

Both groups have high $\mathrm{Zr} / \mathrm{Nb}$ ratios $(\geq 30$ ) (Fig. 8) and are typical depleted Type I ocean-floor basalts according to the classification scheme of Bryan and others (1976). The compositional differences between the two groups coupled with a constant $\mathrm{Zr} / \mathrm{Nb}$ ratio (Fig. 8) are qualitatively consistent with a comagmatic relationship between the two groups. Approximately $50 \%$ crystal fractionation involving olivine, plagioclase, and clinopyroxene is required to generate Group II basalts from Group I basalts.

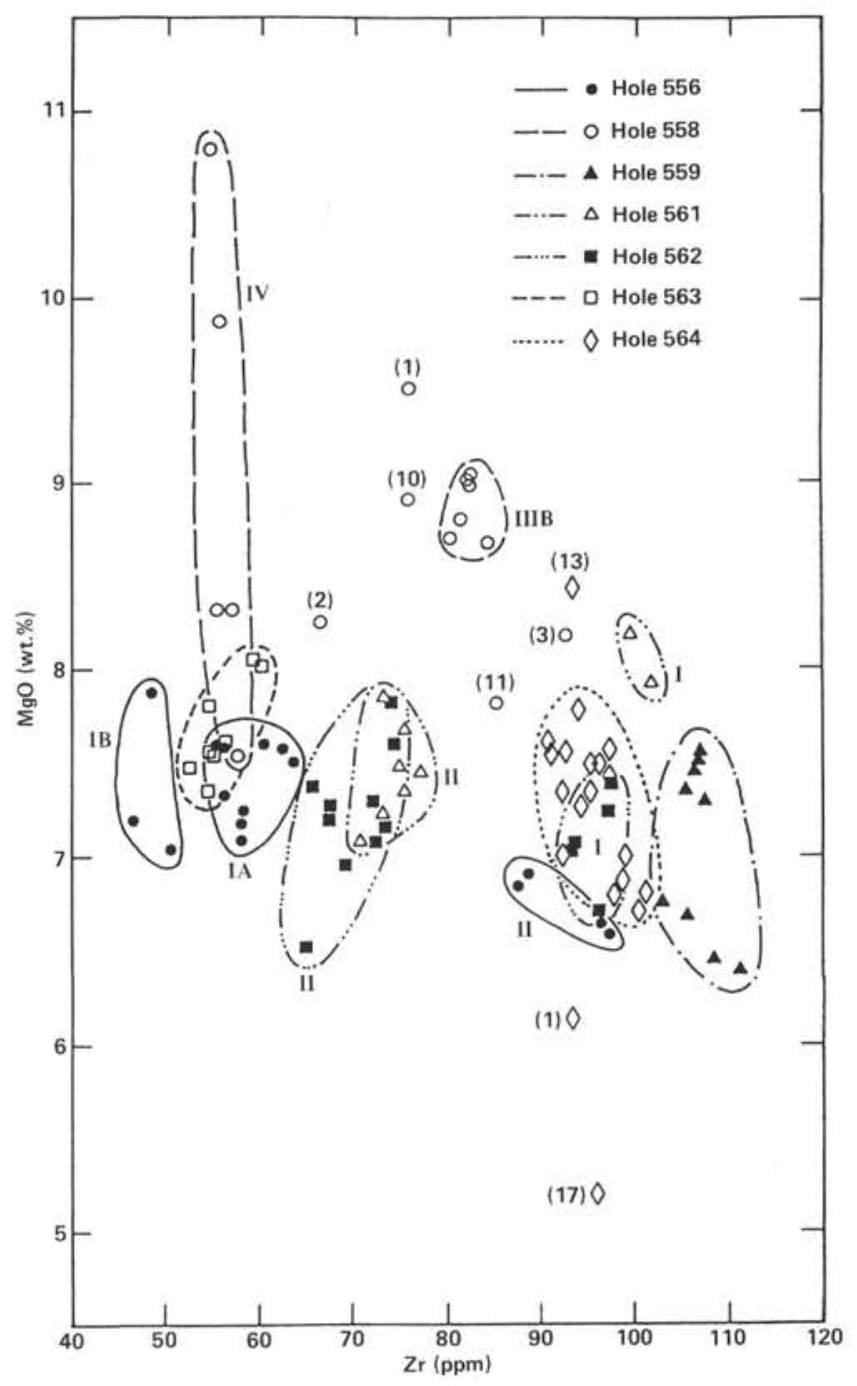

Figure 2. $\mathrm{MgO}$ versus $\mathrm{Zr}$. Enclosures and Roman numerals refer to chemical groups within each hole. (All of the samples from Holes 559,563 , and 564 belong to Chemical Group I.) Arabic numbers in parentheses refer to the University of Massachusetts sample numbers (hole is indicated by shape of data point; see Appendix A tables for the DSDP sample designations for the samples).

It is unlikely, however, that this process is one of simple crystal fractionation. First, the observed phenocryst assemblages of only plagioclase \pm olivine are not consistent with fractionation dominated by clinopyroxene (as is suggested by chemical considerations). Second, the fact that $\mathrm{Ni}$ and $\mathrm{Cr}$ abundances are approximately the same for the two groups, each with different amounts of incompatible elements (Fig. 5), is consistent with the evolution of both groups from a common parental magma. Such inconsistencies may be explained by a combination of fractional crystallization and mixing of consanguineous magmas (Rhodes et al., 1979). This interpretation receives support from the repetitive interlayering of Groups I and II. It is also possible to interpret the geochemical differences in terms of variable degrees of partial melting of a common source (Langmuir et al., 1977; Wood, 1979). In this case, the more enriched 


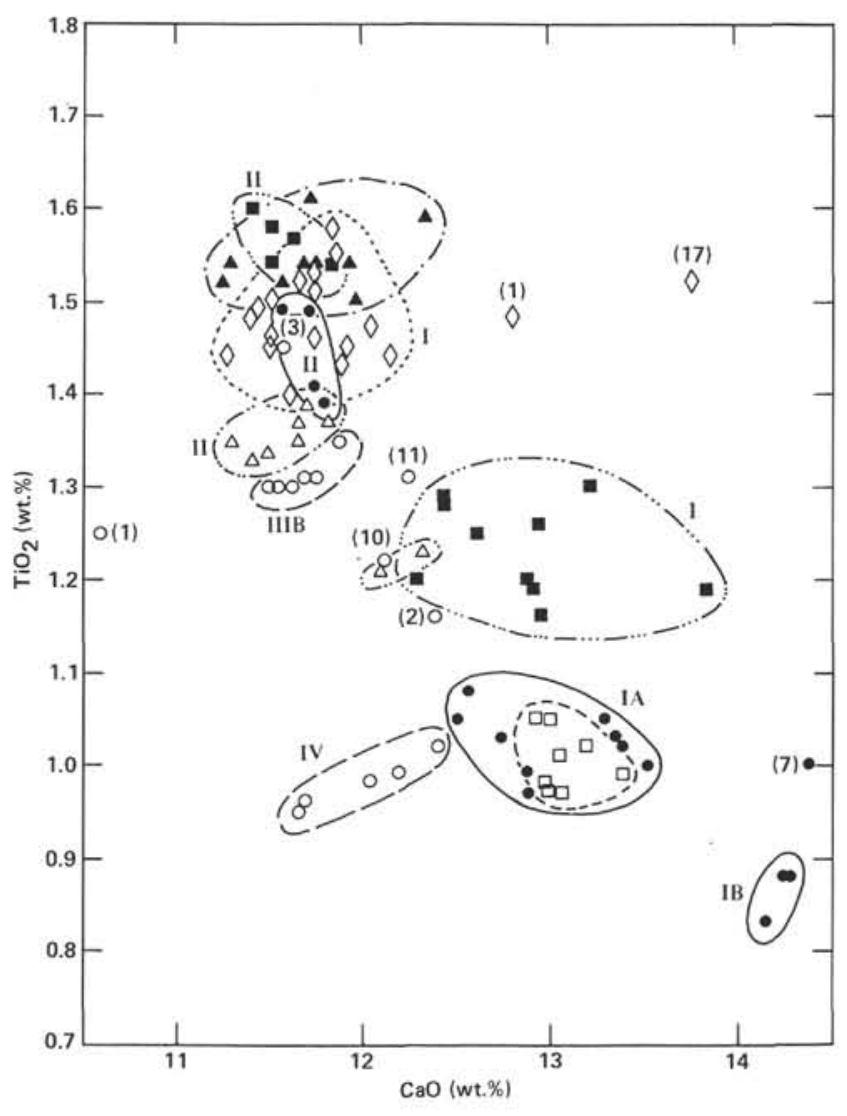

Figure 3. $\mathrm{TiO}_{2}$ versus $\mathrm{CaO}$. Symbols and enclosures are the same as in Figure 2.

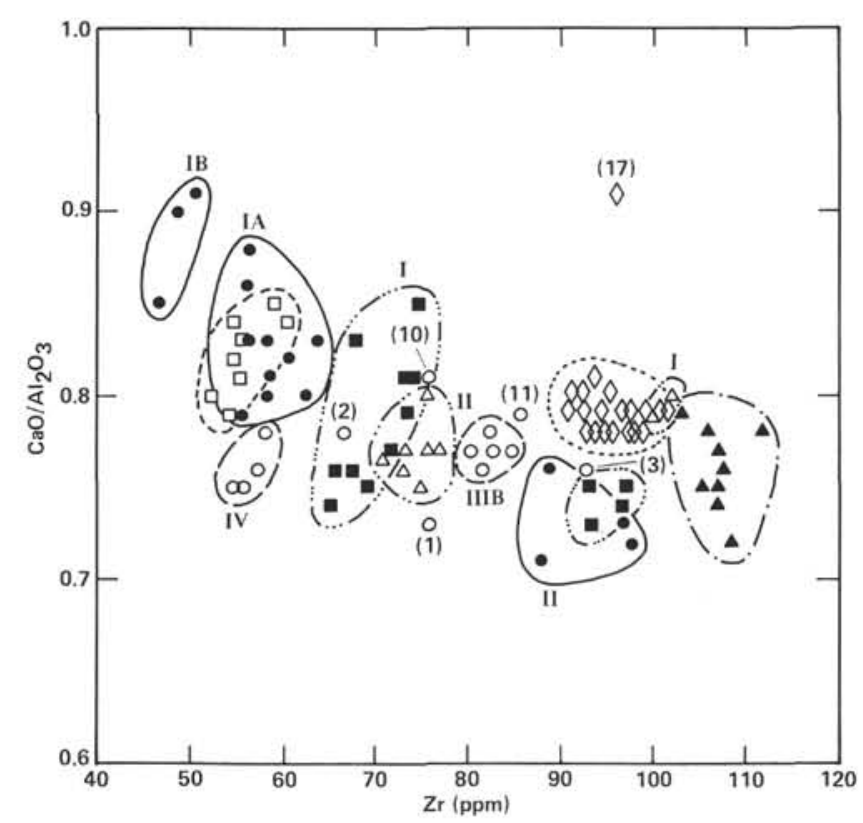

Figure 4. $\mathrm{CaO} / \mathrm{Al}_{2} \mathrm{O}_{3}$ versus $\mathrm{Zr}$. Symbols and enclosures are the same as in Figure 2.
Group II would have been produced by a lesser degree of melting. However, a plot of $\mathrm{Sr}$ versus $\mathrm{Zr}$ (Fig. 6) shows that both groups have about the same concentration of $\mathrm{Sr}(100 \mathrm{ppm})$ for very different concentrations of Zr. This relationship cannot be produced by different degrees of partial melting, but can be the result of fractionation/mixing processes.

\section{Hole 557}

Hole 557 is located near the same flow line as Hole 556, but near Anomaly 5D (18 Ma) closer to the Azores Triple Junction (Fig. 1). Only $3 \mathrm{~m}$ of basement were penetrated before the hole was abandoned because of inclement weather. Our one sample of this core, 557-1, falls into Group II of the shipboard studies (Site 557 chapter, this vol.). It has extremely high incompatible element abundances, $\mathrm{TiO}_{2}$ (3.67 wt.\%), $\mathrm{Zr}$ (216 ppm), Y (41 ppm), $\mathrm{Nb}(26 \mathrm{ppm})$ as well as high $\mathrm{Fe}_{2} \mathrm{O}_{3}{ }^{*}(16.5$ wt. $\%$ ) and $\mathrm{Sr}(299 \mathrm{ppm})$, but very low $\mathrm{MgO}$ (5 wt.\%), $\mathrm{Ni}(38 \mathrm{ppm})$, and $\mathrm{Cr}(19 \mathrm{ppm})$ abundances and a low $\mathrm{Mg}^{\prime}$-value (0.41) (Appendix A, Table 1). Thus, 557-1 is one of the more highly evolved or enriched basalts described to date from the ocean floor (Melson et al., 1977; Basaltic Volcanism Study Project, 1981). $\mathrm{TiO}_{2}$ and FeO* abundances in 557-1 are similar to those of the enriched FeTi basalts of the Galapagos Spreading Center (Anderson et al., 1975; Schilling et al., 1976; Melson et al., 1977). Because of its extremely different abundances and ratios, Hole 557 data are not plotted on Figures 2-8.

The $\mathrm{Zr} / \mathrm{Nb}$ ratio (8) and $\mathrm{Zr} / \mathrm{Y}$ ratio (5) indicate that 557-1 is a Type II ocean-floor basalt (Bryan et al., 1976). The $\mathrm{Zr} / \mathrm{Y}$ ratio is similar to that observed in Holes 407 , $408,410 \mathrm{~A}$, and 413 of DSDP Leg 49 (Tarney et al., 1979), but is higher than the $\mathrm{Zr} / \mathrm{Y}$ ratios (2-4) observed in the other Leg 82 basalts (Fig. 7). It is likely that this basalt was derived from an unusually enriched source. If these basalts were derived from primitive Type II basalts similar to Group IV in Hole 558 (Appendix A, Table 2), the observed increase in incompatible element abundances would suggest as much as $70 \%$ crystal fractionation of olivine, plagioclase, and clinopyroxene. However, the lack of clinopyroxene phenocrysts and the close correlation of $\mathrm{TiO}_{2}$ and $\mathrm{Y}$ abundances to other incompatible element abundances (indicating that clinopyroxene has not been a major fractionating phase) suggest that $557-1$ is enriched by derivation from an enriched source rather than by evolution from a more typical oceanfloor basalt. CIPW norm calculations also indicate a more moderate state of evolution (557-1 is only slightly quartz normative).

\section{Hole 558}

Hole 558 is located between Anomalies 12 and 13 (34-37 Ma) about $50 \mathrm{~km}$ south of the Pico Fracture Zone on a flow line passing through DSDP Leg 37, Hole 335 (approximately $16.5 \mathrm{Ma}$ ), and the FAMOUS area (Recent) (Fig. 1). The 16 samples collected from $153.5 \mathrm{~m}$ of basement are compositionally the most complex of the Leg 82 basalts. The data indicate that four distinct basalt groups and two subgroups have been sampled (Appendix A, Table 2 and Appendix B, Table 2). 


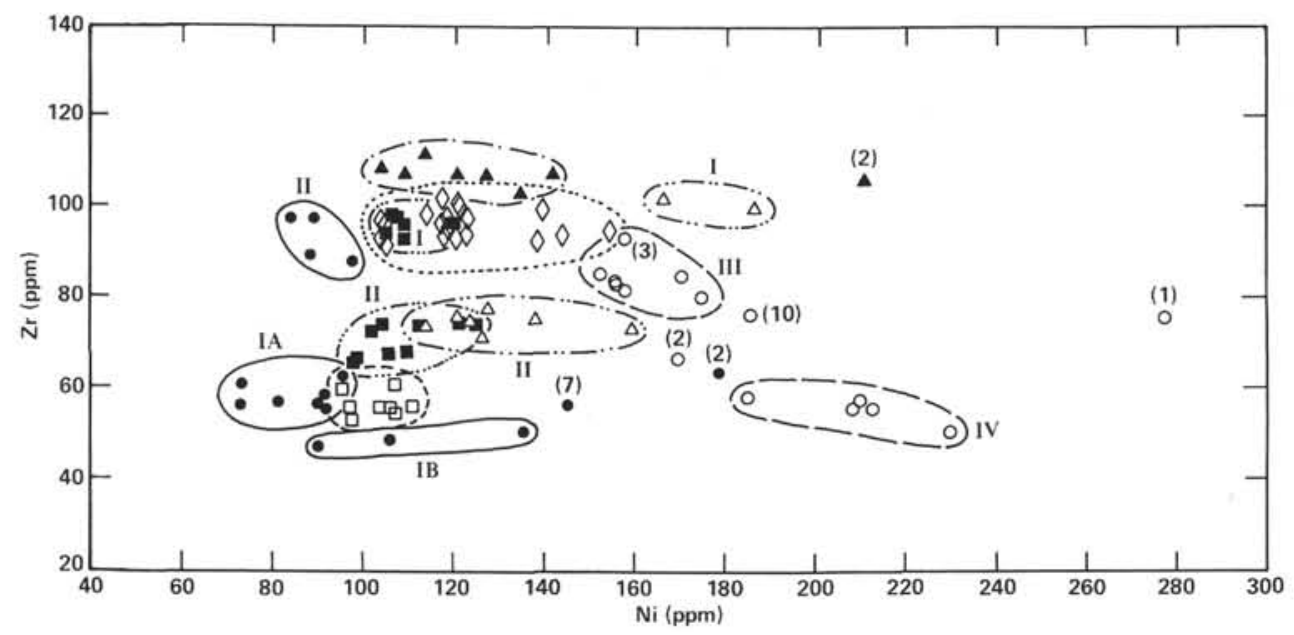

Figure 5. $\mathrm{Zr}$ versus $\mathrm{Ni}$. Symbols and enclosures are the same as in Figure 2.

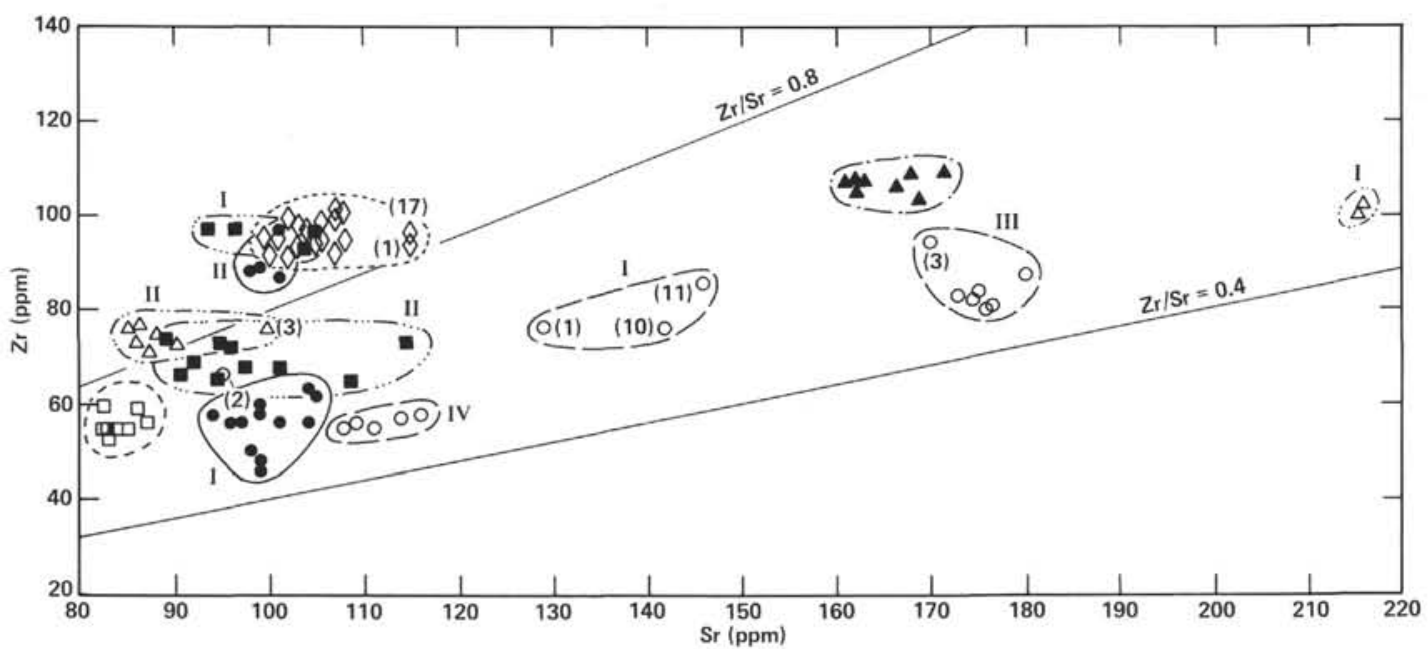

Figure 6. $\mathrm{Zr}$ versus $\mathrm{Sr}$. Symbols and enclosures are the same as in Figure 2. Lines represent $\mathrm{Zr} / \mathrm{Sr}$ ratios.

All of the chemical groups in this study correspond to shipboard groups except that three samples (558-1, 558-10, and 558-11) are included together in Group I because, although not stratigraphically contiguous, they have similar incompatible element abundances and ratios (Appendix A, Table 2; Figs. 7, 8).

Group I has moderate abundances of $\mathrm{MgO}$ (8.8 wt. \%), $\mathrm{CaO}$ (11.7 wt.\%), $\mathrm{Sr}$ (139 ppm), Ni (169 ppm) and $\mathrm{Cr}$ (344 ppm), $\mathrm{Mg}^{\prime}$-values $(0.65)$, and $\mathrm{CaO} / \mathrm{Al}_{2} \mathrm{O}_{3}$ ratios (0.77) (Appendix B, Table 2; Figs. 2-6). The abundances of incompatible elements are moderate as well, $\mathrm{TiO}_{2}$ (1.26 wt. \%), Zr (79 ppm), Nb (9.8 ppm), Y (23 ppm), as are the $\mathrm{Zr} / \mathrm{Y}$ ratios (3.5) (Appendix B, Table 2; Fig. 7). Sample 558-1 has the highest $\mathrm{MgO}$ (9.5 wt.\%), Ni (277 $\mathrm{ppm})$, and $\mathrm{Cr}(510 \mathrm{ppm})$ abundances in Group I and the lowest $\mathrm{CaO}\left(10.6\right.$ wt. \%) contents and $\mathrm{CaO} / \mathrm{Al}_{2} \mathrm{O}_{3}$ ratio (0.73) (Appendix A, Table 2; Figs. 2-5), which could be due to olivine accumulation.

Group II, consisting of one sample, 558-2, also contains moderate abundances of major and trace elements; $\mathrm{MgO}$ (8.3 wt.\%), $\mathrm{CaO}$ (12.4 wt.\%), Ni (170 ppm), $\mathrm{Cr}$ $\left(400 \mathrm{ppm}\right.$ ), and $\mathrm{CaO} / \mathrm{Al}_{2} \mathrm{O}_{3}$ ratio (0.78) (Appendix $\mathrm{A}$,
Table 2; Figs. 2-5). The $\mathrm{Mg}^{\prime}$-value is high (0.67), whereas the $\mathrm{Sr}$ content $(95 \mathrm{ppm})$ is the lowest of all Hole 558 basalts (Fig. 6). Incompatible element abundances are somewhat low: $\mathrm{TiO}_{2}$ (1.2 wt. \%), $\mathrm{Zr}(66 \mathrm{ppm}), \mathrm{Nb}$ (2.3 $\mathrm{ppm})$, and Y (26 ppm). The fact that Group II has the highest $\mathrm{Y}$ content and lowest $\mathrm{Zr} / \mathrm{Y}$ ratio (2.6) for this hole (Fig. 7) precludes the possibility that Group II evolved from any of the other samples in Hole 558 by fractionation of clinopyroxene.

Group III consists of seven samples (558-3 through $558-9)$. It has the lowest $\mathrm{CaO}$ (11.6 wt.\%), Ni (160 ppm), and $\mathrm{Cr}(368 \mathrm{ppm})$ and highest $\mathrm{Sr}(173 \mathrm{ppm}), \mathrm{TiO}_{2}(1.35$ wt.\%), and $\mathrm{Zr}(88 \mathrm{ppm})$ abundances of all samples in Hole 558 (Appendix B, Table 2; Figs. 3, 5, 6). Yet the Ni and $\mathrm{Cr}$ contents are still fairly high, as are $\mathrm{MgO}$ contents (8.7 wt. \%) and $\mathrm{Mg}^{\prime}$-values (0.66) (Figs. 2, 5). This suggests that the samples from Hole 558 are among the most primitive of Leg 82 basalts, even though Group III is the most evolved group at this site.

Within Group III are two subgroups. The single sample (558-3) in Subgroup IIIA differs from the other six samples in Subgroup IIIB; it has lower $\mathrm{MgO}$ (8.2 versus 


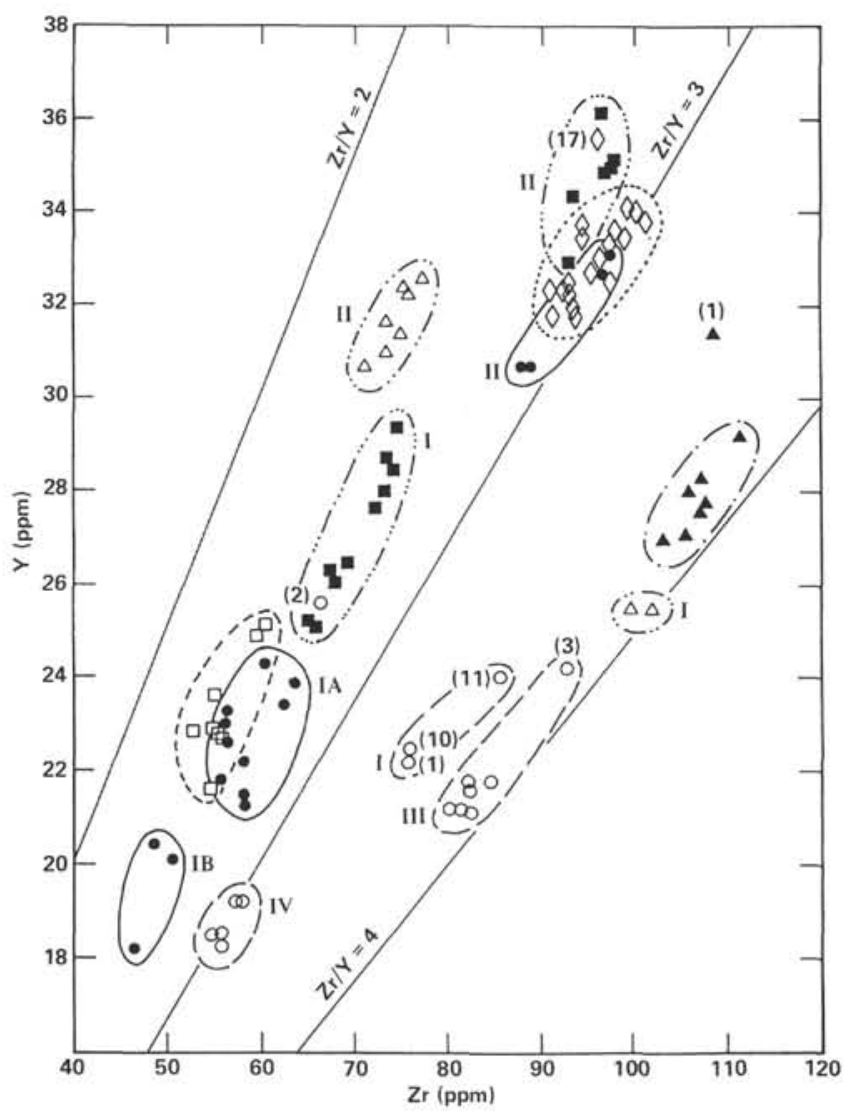

Figure 7. Y versus $\mathrm{Zr}$. Symbols and enclosures are the same as in Figure 2. Lines represent constant $\mathrm{Zr} / \mathrm{Y}$ ratios.

8.9 wt. $\%$ ) contents and $\mathrm{Mg}^{\prime}$-values (0.64 versus 0.67 ) and greater abundances of incompatible elements, $\mathrm{TiO}_{2}$ (1.45 versus 1.31 wt. \%), $\mathrm{Zr}$ (93 versus $82 \mathrm{ppm}$ ), $\mathrm{Nb}$ ( 15.3 versus $13.6 \mathrm{ppm})$, and Y (24 versus $21 \mathrm{ppm})$ (Appendix $\mathrm{B}$, Table 2). The similar $\mathrm{CaO} / \mathrm{Al}_{2} \mathrm{O}_{3}$ ratios $(0.77)$ and $\mathrm{Ni}$ (157 versus $162 \mathrm{ppm})$ and $\mathrm{Cr}(356$ versus 379 ppm) contents for both subgroups (Figs. 4, 5) imply that Subgroups IIIA and IIIB may have either fractionated along closely parallel trends from slightly different parental magmas or undergone mixing during the fractionation process. Because IIIA contains about the same amount of $\mathrm{Sr}$ (170 versus $176 \mathrm{ppm}$ ) and more $\mathrm{Zr}$ than IIIB (Fig. 6), a melting trend is not possible, whereas mixing during fractionation is possible. Although the $\mathrm{Zr} / \mathrm{Y}$ ratios are the same for both subgroups (3.8) (Fig. 7), the abundance of $\mathrm{Y}$ is higher for IIIA than IIIB, also supporting a more complex relationship than simple crystallization dominated by clinopyroxene fractionation.

Group IV, with five samples (558-12 through 558-16) has high $\mathrm{MgO}$ (7.5-10.8 wt.\%), Ni (185-230 ppm) and $\mathrm{Cr}(442-482 \mathrm{ppm})$ contents, and $\mathrm{Mg}^{\prime}$-values $(0.62-0.71)$, with moderate $\mathrm{CaO}(12.1$ wt. \%) and $\mathrm{Sr}(112 \mathrm{ppm})$ contents and $\mathrm{CaO} / \mathrm{Al}_{2} \mathrm{O}_{3}$ ratios $(0.76)$ (Appendix $\mathrm{B}$, Table 2; Figs. 2-6). These basalts exhibit low incompatible element abundances; $\mathrm{TiO}_{2}$ ( $<1$ wt. $\left.\%\right), \mathrm{Zr}(55 \mathrm{ppm}), \mathrm{Nb}$ (7.6 ppm), and $\mathrm{Y}(19 \mathrm{ppm}$ ) and $\mathrm{Zr} / \mathrm{Y}$ ratios (3.0) (Fig. 7). These abundances and ratios make Group IV the most primitive of the Leg 82 basalts. The primitive nature of Group IV basalts is also shown by the trends seen in Fig-

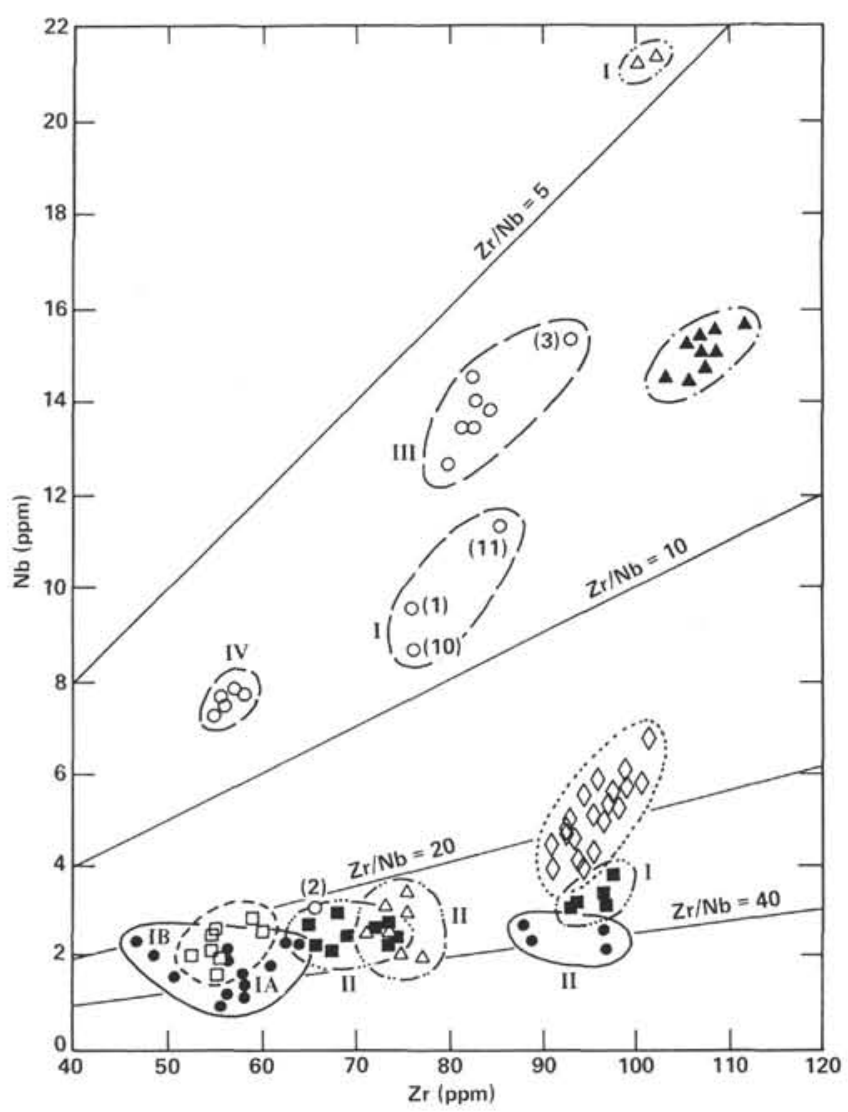

Figure 8 . $\mathrm{Nb}$ versus $\mathrm{Zr}$. Symbols and enclosures are the same as in Figure 2. Lines represent constant $\mathrm{Zr} / \mathrm{Nb}$ ratios.

ures 2, 3, and 5 of $\mathrm{Zr}$ versus $\mathrm{MgO}, \mathrm{CaO}$, and $\mathrm{Ni}$, respectively, which indicate olivine-controlled fractionation.

Within Group IV, Samples 558-13 and 558-16 are possible candidates for primary ocean-floor basalts. They have the highest abundances of $\mathrm{MgO}(10.8$ and $9.9 \mathrm{wt} . \%)$, $\mathrm{Ni}$ (230 and $214 \mathrm{ppm})$ and $\mathrm{Cr}$ (449 and $441 \mathrm{ppm})$, and $\mathrm{Mg}^{\prime}$-values ( 0.71 and 0.69 ) of all Leg 82 basalts (except 558-1 for $\mathrm{Ni}$ ) and low incompatible element abundances (Appendix A, Table 2). They are chemically similar to other proposed primary ocean-floor basalts such as those from DSDP Leg 3 (Frey et al., 1974), the FAMOUS area (Langmuir et al., 1977; White and Bryan, 1977), and the Mid-Atlantic Ridge at $45^{\circ} \mathrm{N}$ (Melson et al., 1977; Rhodes et al., 1979; Basaltic Volcanism Study Project, 1981).

It seems unlikely that the basalts from these four groups are comagmatic. Basalt samples from all four groups, which have comparable $\mathrm{MgO}$ and $\mathrm{Ni}$ abundances, $\mathrm{Mg}^{\prime}$-values, and $\mathrm{CaO} / \mathrm{Al}_{2} \mathrm{O}_{3}$ ratios, have markedly different abundances of $\mathrm{Zr}$ and other incompatible elements (Figs. 2, 4, 5). In addition, these four chemical groups all have different $\mathrm{Zr} / \mathrm{Nb}$ ratios (Fig. 8): Groups I, III, and IV have low values $(8,6$, and 7.5 , respectively), typical of Type II basalts (Bryan et al., 1976), but Group II is somewhat anomalous with a $\mathrm{Zr} / \mathrm{Nb}$ ratio of about 20 (Fig. 8), similar to many basalts sampled on the Juan de Fuca Ridge (Liias and Rhodes, 1982).

REE data were obtained for four representative samples, one from each group (Table 1; Fig. 9A). Samples 558-1, 558-7, and 558-13 (Groups I, III, IV, respective- 

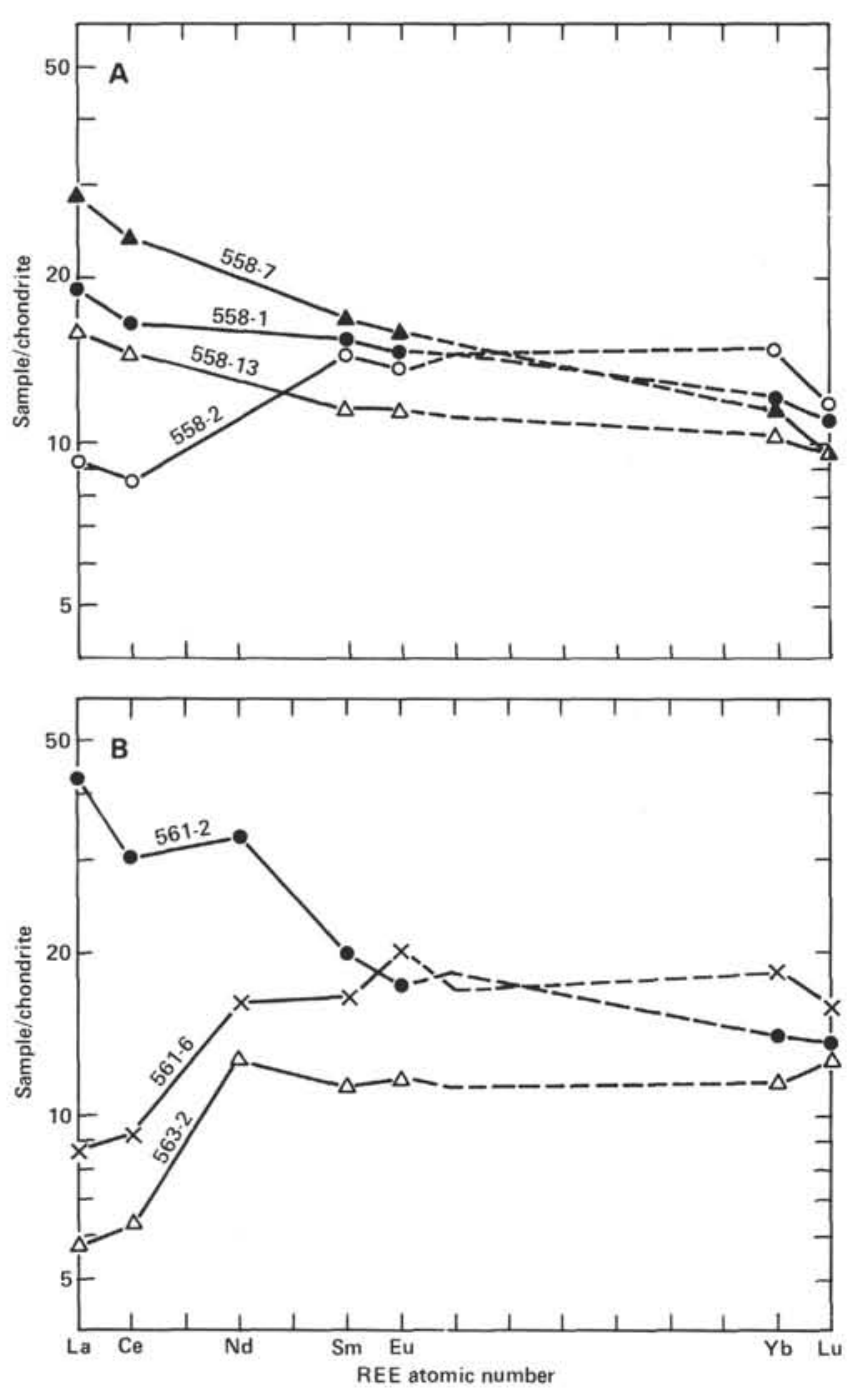

Figure 9. A. Chondrite-normalized rare earth element (REE) abundances for selected basalts in Hole 558. Sample numbers are the simplified numbers used in this study. Complete DSDP designations are located at the top of Appendix A, Table 2. B. Chondritenormalized REE abundances for selected basalts in Holes 561 and 563. Sample numbers are the simplified numbers used for this study. Complete DSDP designations are located at the top of Appendix A, Tables 4 and 6.

ly) all show LREE-enriched patterns with chondrite-normalized (ch) ratios: $(\mathrm{La} / \mathrm{Sm})_{\mathrm{ch}}>1(1.25-1.8)$ and $(\mathrm{La} /$ $\mathrm{Yb})_{\mathrm{ch}}>1$ (1.5-2.5) (Table 1). In marked contrast, Sample 558-2 (Group II) has a LREE-depleted pattern with $(\mathrm{La} / \mathrm{Sm})_{\mathrm{ch}}<1(0.63)$ and $(\mathrm{La} / \mathrm{Yb})_{\mathrm{ch}}<1(0.61)$. Although the $(\mathrm{La} / \mathrm{Sm})_{\text {ch }}$ ratios are variable, the $(\mathrm{La} / \mathrm{Ce})_{\mathrm{ch}}$ ratios are $>1$ (1.09-1.35) for all four groups, similar to other basalts along this flow line, such as those from DSDP Leg 37 (Blanchard et al., 1976) and the FAMOUS area (Langmuir et al., 1977; White and Bryan, 1977).

\section{Hole 559}

Hole 559 is located between Anomalies 12 and 13 (34-37 Ma) midway between the Oceanographer and Hayes fracture zones (Fig. 1). All nine samples from the
$63 \mathrm{~m}$ of basement are similar in composition (Appendix A, Table 3; Appendix B, Table 3) and compose a single chemical group consisting of enriched Type II basalts (Bryan et al., 1976) with typical $\mathrm{Zr} / \mathrm{Nb}$ ratios (7-7.5) (Fig. 8). These basalts have some of the lowest $\mathrm{CaO}$ (11.7 wt. \%) contents and $\mathrm{CaO} / \mathrm{Al}_{2} \mathrm{O}_{3}$ ratios $(0.76)$ and highest incompatible element abundances- $\mathrm{TiO}_{2}(1.54$ wt. \%), $\mathrm{Zr}$ (107 ppm), Y (28 ppm), and $\mathrm{Nb}$ (15 ppm)—of all Leg 82 samples except 557-1 (Appendix A, Tables 1, 3; Appendix B, Table 3; Figs. 3, 4, 7, 8). However, the $\mathrm{MgO}(7.1 \mathrm{wt} . \%)$ and $\mathrm{Ni}(135 \mathrm{ppm})$ contents and the $\mathrm{Mg}^{\prime}$-value (0.59) are higher than expected relative to the concentration of incompatible elements (Figs. 2, 5).

The basalts from Hole 559 show stratigraphically interlayered variations in $\mathrm{MgO}, \mathrm{FeO}^{*}$, and $\mathrm{Mg}^{\prime}$-values. Samples 559-2, 559-3, 559-5, 559-7, and 559-8 have lower $\mathrm{MgO}$ abundances (6.5 versus 7.5 wt. $\%$ ) and $\mathrm{Mg}^{\prime}$-values $(0.56$ versus 0.62$)$ and higher $\mathrm{Fe}_{2} \mathrm{O}_{3}{ }^{*}$ (11.6 versus 10.5 wt. \%) abundances than Samples 559-1, 559-4, 559-6, and 559-9 (Appendix B, Table 3; Fig. 2). This interlayering involving only the elements $\mathrm{Mg}$ and $\mathrm{Fe}$ could be the result of periodic replenishment of a multiply saturated magma by a more-primitive, olivine-rich melt (Rhodes et al., 1979). The relatively high $\mathrm{Ni}$ values (Fig. 5) also suggest that these basalts are enriched in olivine relative to other similarly evolved basalts (Basaltic Volcanism Study Project, 1981).

The incompatible element abundances (Appendix B, Table 3) are consistent with approximately $50 \%$ crystal fractionation from a more primitive Type II magma similar to the Group IV basalts sampled at Hole 558 (Appendix B, Table 2). Low $\mathrm{CaO} / \mathrm{Al}_{2} \mathrm{O}_{3}$ ratios (0.76) (Fig. 4) coupled with high $\mathrm{Zr} / \mathrm{Y}$ ratios (3.8) (Fig. 7) point towards clinopyroxene involvement in the fractionation process. However, clinopyroxene is notably absent from the observed phenocryst assemblage. The discrepancy between the chemistry and petrography, already encountered in Holes 556, 557, and 558, is a common problem for MORB (Dungan and Rhodes, 1978; Basaltic Volcanism Study Project, 1981) and points to a complex petrogenesis involving fractionation and mixing processes.

Sample 559-1 has the highest Y (31.6 ppm) abundance and the lowest $\mathrm{Zr} / \mathrm{Y}$ ratio (3.43) of Hole 559 basalts (Fig. 7) and therefore could not have fractionated from compositions similar to the other samples in Hole 559. Possibly the observed anomalous behavior of 559-1 is a result of mantle heterogeneity or complex melting processes.

\section{Hole 561}

Hole 561 is located near Anomaly 5E (14-17 Ma) east of Hole 559 and along the same flow line (Fig. 1). The $15.1 \mathrm{~m}$ of basement is represented by nine samples that fall into two stratigraphically distinct groups. Group I is represented by two samples in the upper $0.7 \mathrm{~m}$ of the core, and Group II by seven samples in the lower $14.4 \mathrm{~m}$. (Appendix A, Table 4; Appendix B, Table 4).

The upper basalts (Group I) have greater $\mathrm{MgO}(8.1$ versus 7.4 wt. \%), $\mathrm{CaO}$ (12.2 versus $11.6 \mathrm{wt} . \%), \mathrm{Sr}$ (215 versus $89 \mathrm{ppm})$, and $\mathrm{Ni}(176$ versus $130 \mathrm{ppm})$ abun- 
dances and $\mathrm{Mg}^{\prime}$-values (0.64 versus 0.59 ), but lower $\mathrm{Fe}_{2} \mathrm{O}_{3}{ }^{*}$ contents $(9.9$ versus 11.5 wt. \%) than the lower basalts (Group II).

$\mathrm{Zr} / \mathrm{Nb}$ ratios are strikingly different for the two groups (Fig. 8). Group I, with low $\mathrm{Zr} / \mathrm{Nb}$ ratios $(<5)$, is a Type II basalt (Bryan et al., 1976), whereas Group II, which has higher $\mathrm{Zr} / \mathrm{Nb}$ ratios $(>25)$, is a Type I basalt. Two representative samples, 561-2 of Group I and 561-6 of Group II, were analyzed for REE (Table 1; Fig. 9B). Sample 561-2 is LREE enriched with chondrite-normalized ratios $>1:(\mathrm{La} / \mathrm{Ce})_{\mathrm{ch}}=1.39,(\mathrm{La} / \mathrm{Sm})_{\mathrm{ch}}=2.09$, and $(\mathrm{La} / \mathrm{Yb})_{\mathrm{ch}}=2.94$, all typical of LREE-enriched Type II ocean-floor basalts (Bryan et al., 1976). Sample 561-6, however, is a typical LREE-depleted Type I oceanfloor basalt, with chondrite-normalized ratios $<1$ : (La/ $\mathrm{Ce})_{\mathrm{ch}}=0.93,(\mathrm{La} / \mathrm{Sm})_{\mathrm{ch}}=0.52$, and $(\mathrm{La} / \mathrm{Yb})_{\mathrm{ch}}=0.46$. This is in marked contrast to Hole 558 where the $(\mathrm{La} /$ $\mathrm{Ce})_{\text {ch }}$ ratio is fairly constant $(>1)$ even though variations in the $(\mathrm{La} / \mathrm{Sm})_{\text {ch }}$ ratios occur between Groups I and II (Table 1; Figs. 9A and 9B).

Group I has greater $\mathrm{Zr} / \mathrm{Y}$ (4 versus 2.5) (Fig. 7) and $\mathrm{Zr} / \mathrm{TiO}_{2}$ (90 versus 55$)$ ratios and $\mathrm{Zr}$ abundances $(100$ versus $75 \mathrm{ppm})$ than Group II, but lower Y (25 versus $30 \mathrm{ppm})$ and $\mathrm{TiO}_{2}(1.2$ versus $1.4 \mathrm{wt} . \%)$ contents (Appendix B, Table 4). These features, combined with the different $\mathrm{Zr} / \mathrm{Nb}$ and $(\mathrm{La} / \mathrm{Ce})_{\text {ch }}$ ratios, suggest that two distinct parental magmas are required, which is further supported by the two trends of decreasing $\mathrm{Ni}$ abundances at different $\mathrm{Zr}$ concentrations (Fig. 5). The $\mathrm{Nd}$ isotopic ratios (Jenner et al., this vol.) are distinctly different for the two groups and also indicate two distinct sources.

\section{Hole 562}

Hole 562 is located in 14-17 Ma crust near Anomaly 5D along a flow line about $100 \mathrm{~km}$ south of the Hayes Fracture Zone (Fig. 1). Sixteen samples from $90.1 \mathrm{~m}$ of basement fall into two stratigraphically separated chemical groups (Appendix A, Table 5; Appendix B, Table 5). Group I is represented by six samples in the upper $49.5 \mathrm{~m}$ of core and Group II by ten samples in the lower $40.6 \mathrm{~m}$. Both groups have $\mathrm{Zr} / \mathrm{Nb}$ ratios $>20$ (Fig. 8) and are depleted Type I MORB (Bryan et al., 1976).

Group I, which is higher stratigraphically and therefore more recently erupted, is the more evolved of the two groups. It has lower $\mathrm{CaO}$ (11.6 versus 12.9 wt.\%) and $\mathrm{MgO}\left(7.0\right.$ versus 7.2 wt. \%) abundances, $\mathrm{CaO} / \mathrm{Al}_{2} \mathrm{O}_{3}$ ratios (0.74 versus 0.79 ), and $\mathrm{Mg}^{\prime}$-values ( 0.57 versus 0.61 ) (Figs. 2-4). Abundances of incompatible elements, $\mathrm{TiO}_{2}$ (1.6 versus $1.2 \mathrm{wt} . \%$ ), $\mathrm{Zr}$ (96 versus $70 \mathrm{ppm}$ ), and $\mathrm{Y}$ ( 35 versus $27 \mathrm{ppm}$ ), and $\mathrm{Zr} / \mathrm{Y}$ ratios (2.8 versus 2.6 ) (Fig. 7), are correspondingly higher in Group I than Group II. However, Ni (109 versus 108 ppm), Cr (231 versus $257 \mathrm{ppm})$, and $\mathrm{Sr}$ (100 versus $98 \mathrm{ppm}$ ) abundances are similar for the two groups (Figs. 5, 6).

Within Group II, $\mathrm{Al}_{2} \mathrm{O}_{3}$ increases and $\mathrm{CaO} / \mathrm{Al}_{2} \mathrm{O}_{3}$ ratios decrease with decreasing $\mathrm{Zr}$ (Fig. 4) as a consequence of plagioclase accumulation. The most plagioclase phyric samples occur at the high $\mathrm{Al}_{2} \mathrm{O}_{3}$-low $\mathrm{Zr}$ end of the trend.

The above-noted increase in incompatible elements is consistent with about $22-25 \%$ crystal fractionation. The small increase in $\mathrm{Zr} / \mathrm{Y}$ ratios from Group II to Group I and the fact that $\mathrm{TiO}_{2}$ and $\mathrm{Y}$ are behaving less incompatibly than $\mathrm{Zr}$ and $\mathrm{Nb}$ indicate clinopyroxene on the liquidus. Based on these relations and the trends shown in Figure 7, the two groups could be comagmatic, with Group I basalts having evolved from a magma with Group II composition.

However, as in Hole 556, the Ni abundances for the two groups are approximately the same, although abundances of ZR (and other incompatible elements) are different (Appendix B, Table 5; Fig. 5). These Ni-Zr relationships for the two basalt groups may be the result of the mixing of consanguineous magmas (Rhodes et al., 1979), or alternatively, fractionation of distinct parental magmas produced by slightly different amounts of melting of a similar source. Once again, the two chemical groups have the same $\mathrm{Sr}$ concentrations with different $\mathrm{Zr}$ concentrations (Fig. 6). This precludes partial melting and supports the idea of fractionation and magma mixing as proposed for Holes 556 and 558 in this study.

\section{Hole 563}

Hole 563 is located near Anomaly 13 (34-37 Ma) west of Hole 562 and near the same flow line south of the Hayes Fracture Zone (Fig. 1). The eight samples taken from $18 \mathrm{~m}$ of basement compose a single chemical group. These samples have the following major and trace element abundances: $\mathrm{MgO}$ (7.7 wt. \%), $\mathrm{CaO}$ (13 wt.\%), $\mathrm{Fe}_{2} \mathrm{O}_{3}{ }^{*}$ (10.1 wt.\%), $\mathrm{Ni}(103 \mathrm{ppm})$, and $\mathrm{Cr}$ (239 ppm), $\mathrm{Mg}^{\prime}$-values (0.63), and $\mathrm{CaO} / \mathrm{Al}_{2} \mathrm{O}_{3}$ ratios (0.8) (Appendix A, Table 6; Appendix B, Table 6). Abundances of $\mathrm{Sr}$ $(84 \mathrm{ppm})$ and incompatible elements, $\mathrm{TiO}_{2}(1 \mathrm{wt} . \%), \mathrm{Zr}$ $(50 \mathrm{ppm}), \mathrm{Y}(23 \mathrm{ppm})$, and $\mathrm{Nb}(2.3 \mathrm{ppm})$, and $\mathrm{Zr} / \mathrm{Y}$ ratios $(<2.5)$ are low.

As in Hole 559, the samples in Hole 563 show similar stratigraphically interlayered variations in $\mathrm{MgO}$ and $\mathrm{Fe}_{2} \mathrm{O}_{3}{ }^{*}$ abundances and $\mathrm{Mg}^{\prime}$-values (Appendix A, Table 6; Fig. 2). Samples 563-1, 563-2, 563-4, 563-6, and 563-8 have lower $\mathrm{MgO}$ (7.5 versus 8 wt. \%) abundances and $\mathrm{Mg}^{\prime}$-values $(0.62$ versus 0.64$)$ and greater $\mathrm{Fe}_{2} \mathrm{O}_{3}{ }^{*}(10.3$ versus 9.9 wt. \%) abundances than Samples 563-3, 5635, and 563-7. The interlayered fluctuations in these elements could imply periodic replenishment of an evolving magma reservoir by more primitive melts (Rhodes et al., 1979).

As in Hole 562, plagioclase accumulation is indicated both petrographically and chemically. In samples with such accumulations, $\mathrm{MgO}$ and $\mathrm{Zr}$ abundances and $\mathrm{CaO}$ / $\mathrm{Al}_{2} \mathrm{O}_{3}$ ratios decrease whereas $\mathrm{Al}_{2} \mathrm{O}_{3}$ increases with increasing amounts of plagioclase (Figs. 2, 4).

The compositional data (Appendix A, Table 6) indicate that Hole 563 contains some of the more primitive of the Leg 82 samples. Unlike most Leg 82 basalts, however, clinopyroxene fractionation does not appear to be important in the petrogenesis of Hole 563 basalts, an observation further supported by the $\mathrm{Zr} / \mathrm{Y}$ ratios, which remain roughly constant $(\leq 2.5)$ or decrease slightly with increasing $\mathrm{Zr}$ (Fig. 7).

One sample, 563-2, was analyzed for REE. It yielded chondrite-normalized ratios <1: $(\mathrm{La} / \mathrm{Ce})_{\mathrm{ch}}=0.92,(\mathrm{La} /$ $\mathrm{Sm})_{\mathrm{ch}}=0.51$, and $(\mathrm{La} / \mathrm{Yb})_{\mathrm{ch}}=0.49$ (Table 1; Fig. 9B). 
The resulting LREE-depleted pattern, along with $\mathrm{Zr}$ / $\mathrm{Nb}$ ratios $>20$ (Fig. 8), mark Hole 563 samples as depleted Type I basalts (Bryan et al., 1976). Similar results were obtained for other basalts collected south of the Hayes Fracture Zone.

\section{Hole 564}

Hole 564 is located near Anomaly 13 (34-37 Ma) south of the Hayes Fracture Zone, about $10 \mathrm{~km}$ north of Hole 563 (Fig. 1). Twenty samples were taken from $81 \mathrm{~m}$ of basement. These basalts exhibit high incompatible element abundances, $\mathrm{TiO}_{2}(1.5 \mathrm{wt} . \%), \mathrm{Zr}(96 \mathrm{ppm})$, $\mathrm{Y}(33 \mathrm{ppm})$, and $\mathrm{Nb}(5 \mathrm{ppm})$; low abundances of $\mathrm{CaO}$ (11.8 wt. \%) and $\mathrm{Fe}_{2} \mathrm{O}_{3}{ }^{*}$ (11.9 wt.\%); and moderate $\mathrm{MgO}$ (7.2 wt. \%) and $\mathrm{Sr}(105 \mathrm{ppm})$ contents, $\mathrm{Mg}^{\prime}$-values $(0.57)$, and $\mathrm{CaO} / \mathrm{Al}_{2} \mathrm{O}_{3}$ ratios $(0.80)$ (Appendix $\mathrm{A}$, Table 7; Appendix B, Table 7). These compositional characteristics suggest that Hole 564 basalts are fairly evolved, possibly with clinopyroxene on the liquidus.

Sample 564-17 deviates from the compositional relationships exhibited by the other basalts from this hole and may constitute a separate group or subgroup. Its distinctly lower $\mathrm{MgO}$ content (5.2 wt.\%) and $\mathrm{Mg}^{\prime}$-value (0.47) and higher $\mathrm{Fe}_{2} \mathrm{O}_{3}{ }^{*}$ content $(13.1$ wt. \%) suggest that 564-17 is much more evolved than the other samples. Yet the greater $\mathrm{CaO}$ content $(13.8$ wt. $\%)$ and $\mathrm{CaO}$ / $\mathrm{Al}_{2} \mathrm{O}_{3}$ ratio $(0.90)$ and much lower $\mathrm{SiO}_{2}$ content (47 wt. \%) of this basalt are characteristic of more primitive basalts (Basaltic Volcanism Study Project, 1981). The higher $\mathrm{K}_{2} \mathrm{O}$ ( 0.62 versus 0.33 wt. $\left.\%\right), \mathrm{Rb}$ ( 15 versus $\left.6 \mathrm{ppm}\right)$, and $\mathrm{Sr}$ (115 versus $105 \mathrm{ppm})$, coupled with the other major element characteristics, may indicate that extreme seawater alteration has occurred.

In the plot of $\mathrm{Ni}$ versus $\mathrm{Zr}$ (Fig. 5), the Ni content decreases markedly with almost constant $\mathrm{Zr}$ in all Hole 564 samples, suggesting that olivine is the only liquidus phase. However, the $\mathrm{Ni}$ values (117 ppm) appear to be too high relative to the low $\mathrm{CaO}$ contents and $\mathrm{CaO}$ / $\mathrm{Al}_{2} \mathrm{O}_{3}$ ratios and high incompatible element abundances normally associated with a more evolved magma. As in the other holes, this discrepancy in the chemistry implies a complex petrogenesis.

There is a pronounced and systematic change in basalt composition with depth. $\mathrm{MgO}, \mathrm{Ni}$, and $\mathrm{Cr}$ abundances and $\mathrm{Mg}^{\prime}$-values all decrease downhole, whereas $\mathrm{Fe}_{2} \mathrm{O}_{3}{ }^{*}$ and incompatible element $\left(\mathrm{Nb}, \mathrm{Zr}, \mathrm{Y}\right.$, and $\left.\mathrm{TiO}_{2}\right)$ abundances increase (Appendix A, Table 7). The gradual changes of concentration with depth suggest that the earlier erupted magma was more evolved than the more recently erupted magma. Such changes are commensurate with the gradual emptying of a zoned magma chamber or the relatively rapid replenishment of a slowly evolving magma by more primitive melt.

The most striking aspect of chemical variation with depth is the change in $\mathrm{Zr} / \mathrm{Nb}$ ratio, which is greater $(>20)$ near the top of the hole, but gradually decreases downhole to $<15$ (Appendix A, Table 7; Fig. 8). However, this appears to be mostly the result of changing $\mathrm{Nb}$. On the other hand, $\mathrm{Zr} / \mathrm{Y}$ ratios remain essentially constant (2.8-3.0) with the downhole increase in $\mathrm{Zr}$ and $\mathrm{Y}$ (Fig. 7). $\mathrm{Zr} / \mathrm{Nb}$ ratios are unlikely to change during crystal fractionation or more complex processes involving both fractionation and mixing of consanguineous magmas. Therefore, it seems probable that changes in the $\mathrm{Zr} / \mathrm{Nb}$ ratio result from the progressive mixing of a primitive but $\mathrm{Nb}$-enriched melt with one that was evolved but had lower $\mathrm{Zr} / \mathrm{Nb}$ ratios.

Again, Sample 564-17 is different from the others; it has a lower $\mathrm{Zr} / \mathrm{Y}$ ratio (2.7) and greater $\mathrm{Y}$ content (36 ppm) (Fig. 7). This inverse relationship is similar to that exhibited by Sample 559-1. There is no obvious explanation for this anomalous behavior, and further investigation is warranted. Two representative samples, one from the top and one from the bottom of Hole 564, will be analyzed for REE and isotopes.

\section{DISCUSSION}

Numerous isotopic and chemical studies have been made of basalts along the Mid-Atlantic Ridge from the Azores Triple Junction to south of the Hayes Fracture Zone (Fig. 1) (Schilling, 1975; White et al., 1976; O'Nions et al., 1977; Tarney et al., 1979; White and Schilling, 1978; Zindler et al., 1979; Dupré and Allègre, 1980; White and Hoffman, 1982). These studies have shown that the basalts from this area exhibit compositional diversity ranging from primitive to highly evolved and LREE-depleted to LREE-enriched (Types I and II of Bryan et al., 1976).

The holes sampled during Leg 82 (Fig. 1) contain several types of basalts that exhibit a variety of chemical characteristics and may occur together within a given hole (Table 1; Appendix A, Tables 1-7; Appendix B, Tables 1-7). Most of these chemical groups are uniform in composition, and, in general, simple crystal fractionation cannot be readily documented by chemical variation within groups. The exceptions are the olivine fractionation trend observed in Hole 558 (Group IV) (Figs. $2,3,5)$ and the plagioclase accumulation trends observed in Hole 562 (Group II) and Hole 563 (Figs. 2, 4).

Chemical variation, however, does exist between groups within a given hole. In Holes 556, 558, and 562 (Fig. 1), the decreasing $\mathrm{CaO} / \mathrm{Al}_{2} \mathrm{O}_{3}$ ratios and increasing $\mathrm{Zr} / \mathrm{Y}$ ratios (Figs. 4 and 7) seem to indicate that one group may have evolved from another by multiply saturated crystal fractionation. However, several lines of evidence indicate that the chemical variation between groups is not compatible with simple crystal fractionation. First, in these same three holes there is a discrepancy between estimates of the state of magmatic evolution based on major and compatible trace elements (e.g., $\mathrm{MgO}, \mathrm{CaO}$, $\mathrm{Ni}, \mathrm{Cr}$ contents, $\mathrm{Mg}$ '-value, $\mathrm{CaO} / \mathrm{Al}_{2} \mathrm{O}_{3}$ ratios) and that based on incompatible elements $\left(\mathrm{TiO}_{2}, \mathrm{Zr}, \mathrm{Nb}, \mathrm{Y}\right)(\mathrm{Ap}-$ pendix A, Tables 2, 3, 5; Figs. 2-5). This discrepancy is clearly evident in $\mathrm{Zr}$ versus $\mathrm{MgO}$ and $\mathrm{Ni}$ (Figs. 2, 5), where associated groups in Holes 556, 558, and 562 have similar $\mathrm{MgO}$ and $\mathrm{Ni}$ abundances, but markedly different $\mathrm{Zr}$ contents. This phenomenon may imply that (1) each of the groups evolved from slightly different parental magmas or (2) the groups within each hole are related to a common parental magma by interplay of mixing and fractionation (Rhodes et al., 1979). The latter hypothesis receives further support from the existence 
within Holes 556, 558, and 562 of different chemical groups with the same $\mathrm{Sr}$ but different $\mathrm{Zr}$ contents (Fig. 6). This cannot be explained by partial melting.

The stratigraphic interlayering of different chemical groups within the same hole (Holes 556 and 558) (Appendix A, Tables 1 and 2) indicates that similar magma compositions were episodically erupted. This supports the involvement of complex fractionation-mixing processes in the petrogenesis of these basalts. Further support comes from interlayered variations in $\mathrm{Mg}^{\prime}$-values in Holes 559 and 563 (Fig. 2), which could be due to repeated influxes of a more primitive melt into a more evolved magma (Rhodes et al., 1979). Further evidence for fractionation-mixing is the commonly observed discrepancy between the chemical criteria that appear to require clinopyroxene fractionation and the absence of clinopyroxene phenocrysts in any of the Leg 82 samples. This is a common problem in ocean-floor basalt petrogenesis (Dungan and Rhodes, 1978; Basaltic Volcanism Study Project, 1981) and is probably indicative of mixing between more-primitive and more fractionated magmas (Rhodes et al., 1979).

The systematic downhole trends in major and trace element abundances in Hole 564 (Appendix A, Table 7; Fig. 8) from relatively primitive to more evolved basalts is compatible with mixing of distinct magmas rather than simple crystal fractionation (Rhodes et al., 1979; Batiza and Johnson, 1980).

To gain a better understanding of Leg 82 basalt petrogenesis, it is important to assess the roles of mantle heterogeneity, complex melting, and melt segregation in the generation of the chemical diversity observed both within and between holes, especially Holes 558 and 561 (Table 1; Figs. 1-9; Appendix A, Tables 2, 4). For example, basalts with distinctly incompatible trace element ratios $\mathrm{Zr} / \mathrm{Y}, \mathrm{Zr} / \mathrm{Nb}$, and LREE/HREE (Figs. 7-9B) sampled within a single drill hole (Holes 558 and 561) have been cited as evidence for large-scale mantle heterogeneity involving a "depleted" upper mantle with mantle plumes upwelling from a more "fertile" deeper mantle layer (Schilling, 1973; Schilling et al., 1976; White and Schilling, 1978). Alternatively, mantle heterogeneity models involving mantle "blobs" (Schilling, 1975; Schilling et al., 1982), or pervasive small-scale veining or metasomatism of the upper mantle (Hanson, 1977; Zindler et al., 1979) have also been proposed. Complex melting and melt segregation in an otherwise homogeneous mantle (Langmuir et al., 1977; Wood, 1979) may cause similar differences in incompatible element and REE abundances, but not in ratios of highly incompatible elements $(\mathrm{La} / \mathrm{Ce})_{\text {ch }}$ or $\mathrm{Nd}$ isotopes.

To evaluate these models it is necessary to develop a concept of the scale of heterogeneity with respect to both time and distance. The studies referenced above suggest the possibility of mantle "domains." For example, it appears that there is a boundary at about $33^{\circ} \mathrm{N}$ in the vicinity of the Hayes Fracture Zone separating depleted (Type I) MORBs (Bryan et al., 1976) to the south from enriched (Type II) basalts associated with the topographic high of the Azores Platform (White and Schilling, 1978; Bougault and Treuil, 1980).
In this study, basalts from holes drilled south of the Hayes Fracture Zone (Holes 562, 563, 564) (Fig. 1) are depleted in incompatible trace elements as expected. However, north of the Hayes Fracture Zone, basalts are both enriched (Holes 557 and 559) and depleted (Hole 556) in incompatible elements. At two sites (Holes 558 and 561), both types occur within the same hole (Figs. 1, 8, 9A, 9B). As other studies have shown (Blanchard et al., 1976; Langmuir et al., 1977; Tarney et al., 1979; Wood, 1979; Wood et al., 1979; Zindler et al., 1979), this close spatial association of enriched and depleted basalts is not uncommon. The occurrence of depleted basalts in older Hole $556(30-34 \mathrm{Ma})$ and enriched basalts in younger Hole $557(18 \mathrm{Ma})$ along a flow line from the Azores hot spot (Fig. 1) suggests that mantle anomalies are transient features, perhaps adding support to the mantle blob hypothesis (Schilling, 1975; Schilling et al., 1982) or small-scale mantle veining (Hanson, 1977; Zindler et al., 1979). In Hole 561, Groups I and II are not stratigraphically interlayered and have distinctly different ratios for the highly incompatible elements, $\mathrm{Zr} / \mathrm{Nb}$ and $(\mathrm{La} / \mathrm{Ce})_{\mathrm{ch}}$, in addition to differences in $\mathrm{Zr} / \mathrm{Y},(\mathrm{La} / \mathrm{Sm})_{\mathrm{ch}}$, and $(\mathrm{La} / \mathrm{Yb})_{\text {ch }}$ ratios (Table 1; Figs. 7, 8, 9B). These traits suggest that Hole 561 basalts are derived from two distinct sources. Nd isotopic data (Jenner et al., this vol.) and geochemical data point to an LREE-enriched source for Group I and an LREE-depleted source for Group II (Table 1; Fig. 9B). The scale of the source heterogeneity cannot be pinpointed, although the presence within a single hole of magmas from two different sources may imply pervasive, small-scale heterogeneity such as mantle veining (Hanson, 1977; Zindler et al., 1979). The occurrence of only enriched basalts in older Hole 559 (34-37 Ma) along the same flow line as younger Hole 561 (14-17 Ma) (Fig. 1) could also be the result of a more transient mantle anomaly.

As noted above, variable incompatible and REE ratios within the same hole (such as Holes 558 and 561) may indicate either mantle heterogeneity or complex melting of a single source. If complex melting is involved, the ratios of the very highly incompatible elements, such as $\mathrm{Zr} / \mathrm{Nb}$ and especially $(\mathrm{La} / \mathrm{Ce})_{\mathrm{ch}}$, should remain the same, whereas other ratios such as $\mathrm{Zr} / \mathrm{Y},(\mathrm{La} / \mathrm{Sm})_{\mathrm{ch}}$, and $(\mathrm{La} / \mathrm{Yb})_{\mathrm{ch}}$ may vary (Langmuir et al., 1977; Wood, 1979). This is seen in Hole 558 where the $(\mathrm{La} / \mathrm{Ce})_{\mathrm{ch}}$ ratios are about the same (1.09-1.35) for all four groups (Table 1; Fig. 9A). In contrast, other incompatible and REE ratios vary from LREE enriched (Groups I, III, and IV) to LREE depleted (Group II) (Table 1; Figs. 7, 8, 9A; Appendix B, Table 2).

The data are not compatible with a petrogenesis involving only complex melting because $\mathrm{Zr} / \mathrm{Nb}$ ratios vary considerably between Groups I, III, and IV (approximately 6-9) and Group II (20) (Fig. 8). Therefore, mantle heterogeneity may be indicated as well. The Nd isotopic ratios for Hole 558 basalts are almost identical for all four groups (Jenner et al., this vol.), so large-scale plume-related mantle heterogeneity involving two different sources does not seem likely.

A more plausible possibility is smaller-scale mantle veining and/or metasomatism (Hanson, 1977; Zindler 
et al., 1979) that may generate the highly variable incompatible element ratios and crossing REE pattern observed in Hole 558, along with the constant $(\mathrm{La} / \mathrm{Ce})_{\text {ch }}$ and $\mathrm{Nd}$ isotopic ratios. Similarly, the repetitive interlayering of diverse magmas within the same hole does not support large-scale mantle heterogeneity. Variation in trace element ratios and crossing REE patterns appear to be restricted to regions of high volcanic activity along elevated ridge segments in hot-spot areas. Other examples are the Juan de Fuca Ridge (Liias and Rhodes, 1982); Iceland (Wood, 1979; Zindler et al., 1979; Schilling et al., 1982); FAMOUS (Langmuir et al., 1977; White and Bryan, 1977); and Hole 558 (site chapter, Site 558, this vol.). The observation that such highly variable basalt types appear to be confined to hot-spot areas suggests small-scale heterogeneity as well as complex melting.

Basalts in Hole 556 have a drastically different chemical signature from the basalts in Hole 557 (Appendix A, Table 1) even though both holes were drilled on the same flow line through the Azores Triple Junction (Fig. 1). This chemical difference, along with the abrupt changes in the $\mathrm{Zr} / \mathrm{Nb}$ ratios and REE patterns between chemical groups within Holes 558 and 561 (Figs. 8, 9A, 9B), is counter to the more gradual transitions expected between Type I and II basalts in plume or mantle blob situations (Schilling, 1975). The basalts from Leg 82 appear to have undergone a complex petrogenesis involving smallscale mantle heterogeneity (veining or metasomatism), complex melting, and mixing-fractionation processes.

\section{CONCLUSIONS}

1. There is no evidence for simple crystal fractionation within or between chemical groups, except for Hole 558 (Group IV), Hole 562 (Group II), and Hole 563 as discussed above.

2. The concept of widespread, complex fractionationmixing processes is supported by several lines of evidence: (1) similar $\mathrm{MgO}, \mathrm{Ni}$, and $\mathrm{Sr}$ abundances with different amounts of incompatible elements in different chemical groups within the same hole; (2) episodic eruptions of similar magmas within the same hole; (3) stratigraphic interlayering of basalts with changing $\mathrm{Mg}^{\prime}$-values in Holes 559 and 563 , suggesting that multiply saturated magmas were periodically replenished by more primitive melt; and (4) discrepancy between chemical composition requiring clinopyroxene fractionation and the lack of clinopyroxene phenocrysts in the samples, a widely observed problem in ocean-floor basalt petrogenesis.

3. The Hayes Fracture Zone appears to be a "domain" boundary between the depleted Type I basalts in the south and the highly variable basalts in the area between the Hayes Fracture Zone and the Azores Triple Junction (Fig. 1).

4. Hole 557 is one of the most highly enriched and/ or evolved basalts sampled in the Atlantic Ocean (or anywhere else) (Melson et al., 1977; Basalt Volcanism Study Project, 1981). The composition of Sample 557-1 most closely resembles the FeTi basalts at the Galapagos Spreading Center (Schilling et al., 1976; Melson et al., 1977).
5. Although incompatible and REE ratios vary from depleted to enriched in Hole $558,(\mathrm{La} / \mathrm{Ce})_{\text {ch }}$ ratios $(1.09-$ 1.35) (Table 1; Fig. 9A) and Nd isotopic ratios (Jenner et al., this vol.) are nearly the same for all four groups in Hole 558. These constant ratios suggest that complex melting of a single source is probably the main process generating the observed compositional variations, although the varying $\mathrm{Zr} / \mathrm{Nb}$ ratios (Fig. 8) may imply source variability on a small scale.

6. Variations in trace element ratios and crossing REE patterns appear to be restricted to the region of high volcanic activity along elevated ridge segments in a hotspot area (in this case, the Azores Platform) (Fig. 1).

7. Two distinct sources are indicated for Hole 561 because the two (noninterlayered) chemical groups have distinctly different, highly incompatible element ratios, including $(\mathrm{La} / \mathrm{Ce})_{\mathrm{ch}}$ (Table 1; Fig. 9B) and $143_{\mathrm{Nd}} / 144_{\mathrm{Nd}}$ (Jenner et al., this vol.).

8. The concept of more pervasive, small-scale mantle heterogeneity such as veining and/or metasomatism rather than a large-scale mantle plume or mantle blobs receives support from several lines of evidence: (1) restriction of high variability in trace element and REE ratios to hot-spot areas (Holes 556-561); (2) abrupt changes in $\mathrm{Zr} / \mathrm{Nb}$ ratios (Fig. 8), REE patterns (Table 1; Figs. 9A and $9 \mathrm{~B}$ ), and $\mathrm{Nd}$ isotopic ratios (Jenner et al., this vol.) between different groups within the same hole (Holes 558 and 561); (3) drastic differences in composition and incompatible element ratios between the older, depleted basalts in Hole 556 (30-34 Ma) and the younger, highly enriched FeTi basalt in Hole 557 (18 Ma) (Appendix A, Table 1), which are about $22 \mathrm{Ma}$ apart along the flow line passing through the Azores Triple Junction (Fig. 1); and (4) the existence of enriched basalts in older Hole 559 (34-37 Ma) and of both enriched and depleted basalts in younger Hole 561 (14-17 Ma) along the same flow line between the Oceanographer and Hayes fracture zones (Fig. 1).

9. The Azores hot-spot anomaly has existed in its present configuration for at least $18 \mathrm{Ma}$ (Hole 557), but less than 30-34 Ma (Hole 556) (Fig. 1).

\section{ACKNOWLEDGMENTS}

We wish to thank the following people for their help in completing this study: F. Frey for use of the MIT INAA laboratory and P. Ila for sample preparation and instruction in using the lab; Marie Litterer for drafting the figures; Gerda Kunkel for typing the tables; and Karen Thatcher of Words-Worth for typing the manuscript and additional tables.

We also wish to express our appreciation to John F. Bender and John Longhi for their many helpful suggestions and meticulous care in reviewing this paper.

This research was funded by NSF Grant $\# 7826330$.

\section{REFERENCES}

Anderson, R. N., Clague, D. A., Klitgord, K. D., Marshall, M., and Nishimori, R. K,. 1975. Magnetic and petrologic variations along the Galapagos Spreading Center and their relation to the Galapagos melting anomaly. Geol. Soc. Am. Bull., 86:683-694.

Basaltic Volcanism Study Project, 1981. Basaltic Volcanism on the Terrestrial Planets: New York (Pergamon Press), pp. 132-160.

Batiza, R., and Johnson, J. R., 1980. Trace element and isotopic evidence for magma mixing in alkalic and transitional basalts near the East Pacific Rise at $8^{\circ} \mathrm{N}$. In Rosendahl, B.R., Hekinian, R., et 
al., Init. Repts. DSDP, 54: Washington (U.S. Govt. Printing Office), 63-69.

Blanchard, D. P., Rhodes, J. M., Dungan, M. A., Rodgers, K. V., Donaldson, C. H., Brannon, J. C., Jacobs, J. W., and Gibson, E. K., 1976. Chemistry and petrology of basalts from Leg 37 of the Deep Sea Drilling Project. J. Geophys. Res., 81:4231-4246.

Bougault, H., and Treuil, M., 1980. Mid-Atlantic Ridge: zero age geochemical variations between Azores and $22^{\circ} \mathrm{N}$. Nature, 286: 209-212.

Bryan, W. B, Thompson, G., Frey, F. A., and Dickey, J. J., 1976. Inferred settings and differentiation in basalts from the Deep Sea Drilling Project. J. Geophys. Res., 81:4285-4304.

Dungan, M. A., and Rhodes, J. M., 1978. Residual glasses and melt inclusions in basalts from DSDP Legs 45 and 46: evidence for magma mixing. Contrib. Mineral. Petrol., 67:417-431.

Dupré, B., and Allègre, C. J,. 1980. Pb-Sr-Nd isotopic correlation and the chemistry of the North Atlantic mantle. Nature, 286:17-22.

Frey, F. A., Bryan, W. B., and Thompson, G., 1974. Atlantic Ocean floor: geochemistry and petrology of basalts from Legs 2 and 3 of the Deep Sea Drilling Project. J. Geophys. Res., 79:5507-5527.

Hanson, G. N., 1977. Geochemical evolution of the sub-oceanic mantle. J. Geol. Soc. London, 134:235-253.

Jacobs, J. W., Korotev, R. L., Blanchard, D. P., and Haskin, L. A., 1977. A well-tested procedure for instrumental neutron activation analysis of silicate rocks and minerals. J. Radioanal. Chem., 40: 93-114.

Langmuir, C. H., Bender, J. F., Bence, A. E., Hanson, G. N., and Taylor, S. R., 1977. Petrogenesis of basalts from the FAMOUS area: Mid-Atlantic Ridge. Earth Plant. Sci. Lett., 36:133-156.

Liias, R. A., and Rhodes, J. M., 1982. Does a mantle plume influence basalt composition along the Juan de Fuca Ridge? EOS, Trans. Am. Geophys. Union, 63:1153-1154. (Abstract)

Melson, W. G., Byerly, G. R., Nelen, J. A., O'Hearn, T., Wright, T. L., and Vallier, T. L., 1977. A catalog of the major element chemistry of abyssal volcanic glasses. Smithson. Contrib. Earth Sci., 19:31-60.

Melson, W. G., and O'Hearn, T., 1979. Basaltic glass erupted along the Mid-Atlantic Ridge between $0-37^{\circ} \mathrm{N}$; relationships between composition and latitude. In Talwani, M., Harrison, C. G., and Hayes, D. E. (Eds.), Deep Drilling Results in the Atlantic Ocean: Ocean Crust: Washington (Am. Geophys. Union), pp. 249-261.

Norrish, K., and Chappell, B. W., 1967. X-ray fluorescence spectrometry. In Zussman, J. (Ed.), Physical Methods in Determinative Mineralogy: New York (Academic Press), pp. 161-214.

Norrish, K., and Hutton, J. T., 1969. An accurate X-ray spectrographic method for the analysis of a wide range of geological samples. Geochim. Cosmochim. Acta, 33:431-453.

O'Nions, R. K., Hamilton, P. J., and Evensen, N. M., 1977. Variation in ${ }^{143} \mathrm{Nd} /{ }^{144} \mathrm{Nd}$ and ${ }^{87} \mathrm{Sr} /{ }^{86} \mathrm{Sr}$ ratios in oceanic basalts. Earth Planet Sci. Lett., 34:13-22.
Reynolds, R. C., 1967. Matrix corrections in trace element analysis by $\mathrm{X}$-ray fluorescence: estimation of the mass absorption coefficient by Compton scattering. Am. Mineral., 48:1133-1143.

Rhodes, J. M., Dungan, M. A., Blanchard, D. P., and Long, P. E., 1979. Magma mixing at mid-ocean ridges: evidence from basalts drilled near $22^{\circ} \mathrm{N}$ on the Mid-Atlantic ridge. Tectonophysics, 55: 36-61.

Schilling, J.-G., 1973. Iceland mantle plume: geochemical study of Reykjanes Ridge. Nature, 242:565-575. 1975. Azores mantle blob: Rare earth evidence. Earth Planet. Sci. Lett., 25:103-115.

Schilling, J.-G., Anderson, R. N., and Vogt, P., 1976. Rare earth, Fe, and $\mathrm{Ti}$ variations along the Galapagos spreading centre, and their relationship to the Galapagos mantle plume. Nature, 261:108-113.

Schilling, J.-G., Meyer, P. S., and Kingsley, R. H., 1982. Evolution of the Iceland hot spot. Nature, 296:313-320.

Tarney, J., Wood, D. A., Varet, J., Saunders, A. D., and Cann, J. R., 1979. Nature of mantle heterogeneity in the North Atlantic: evidence from Leg 49 basalts. Proc. Second M. Ewing Symp., pp. 285-301.

White, W. M., and Bryan, W. B., 1977. Sr-isotope, K, Rb, Cs, Sr, Ba and rare-earth geochemistry of basalts from the FAMOUS area. Geol. Soc. Am. Bull., 88:571-576.

White, W. M., and Hofmann, A. W., 1982. Sr and Nd isotope geochemistry of oceanic basalts and mantle evolution. Nature, 296: 821-825.

White, W. M., and Schilling, J.-G., 1978. The nature and origin of geochemical variation in Mid-Atlantic Ridge basalts from central North Atlantic. Geochim. Cosmochim. Acta, 42:1501-1516.

White, W. M., Schilling, J.-G., and Hart, S. R., 1976. Evidence for the Azores mantle plume from strontium isotope geochemistry of the central North Atlantic. Nature, 263:659-663.

Wood, D. A., 1979. Dynamic partial melting: its application to the petrogenesis of basalts erupted in Iceland, the Faeroe Islands, the Isle of Skye (Scotland) and the Troodos Massif (Cypress). Geochim. Cosmochim. Acta, 43:1031-1046.

Wood, D. A., Tarney, J., Varet, J., Saunders, A. A., Bougault, H., Joron, J. L., Treuil, M., and Cann, J., 1979. Geochemistry of basalts drilled in the North Atlantic by IPOD Leg 49: implications for mantle heterogeneity. Earth Planet. Sci. Lett., 42:77-97.

Zindler, A., Hart, S. R., Frey, F. A., and Jakobsson, S. P., 1979. Nd and $\mathrm{Sr}$ isotope ratios and rare earth element abundances in Reykjanes Peninsula basalts: evidence for mantle heterogeneity beneath Iceland. Earth Planet. Sci. Lett., 45:249-262.

Date of Initial Receipt: 18 November 1983

Date of Acceptance: 4 April 1984 


\section{APPENDIX A}

Chemical Compositions of Basalts from Leg 82

Note to Appendix A tables: Chemical group refers to chemical groups discussed in text. $\mathrm{Fe}_{2} \mathrm{O}_{3}{ }^{*}$ and $\mathrm{FeO}^{+}$refer to total $\mathrm{Fe}$ expressed as $\mathrm{Fe}^{3+}$ and $\mathrm{Fe}^{2+}$, respectively. Calculation of $\mathrm{Mg}^{\prime}$-value discussed in text $\left(\mathrm{Mg} /\left[\mathrm{Mg}+\mathrm{Fe}^{2}\right]\right)$. Small discrepancies in totals may be attributed to rounding.

Table 1. Holes 556 and 557.

\begin{tabular}{|c|c|c|c|c|c|c|c|c|c|c|c|c|c|c|c|c|c|c|}
\hline $\begin{array}{l}\text { Univ. Mass. sample no. } \\
\text { Core-Section } \\
\text { (interval in } \mathrm{cm} \text { ) } \\
\text { Sub-bottom depth (m) } \\
\text { Chemical group }\end{array}$ & $\begin{array}{c}556-1 \\
\text { Hole } 556 \\
2-1 \\
74-76 \\
462.25 \\
1 \mathrm{AA}\end{array}$ & $\begin{array}{c}556-2 \\
\text { Hole } 556 \\
2-2 \\
141-144 \\
464.43 \\
1 \mathrm{~A}\end{array}$ & $\begin{array}{c}556-3 \\
\text { Hole } 556 \\
2-5 \\
26-28 \\
467.77 \\
\text { II }\end{array}$ & $\begin{array}{c}556-4 \\
\text { Hole } 556 \\
3-3 \\
66-69 \\
474.77 \\
\text { II }\end{array}$ & $\begin{array}{c}556-5 \\
\text { Hole } 556 \\
5-1 \\
99-102 \\
490.01 \\
\text { II }\end{array}$ & $\begin{array}{c}556-6 \\
\text { Hole } 556 \\
6-5 \\
64-67 \\
504.66 \\
\text { II }\end{array}$ & $\begin{array}{c}556-7 \\
\text { Hole } 556 \\
6-6 \\
108-111 \\
506.60 \\
1 A\end{array}$ & $\begin{array}{c}556-8 \\
\text { Hole } 556 \\
7-1 \\
128-132 \\
508.30 \\
1 A\end{array}$ & $\begin{array}{c}556-9 \\
\text { Hole } 556 \\
7-3 \\
83-86 \\
510.85 \\
1 A\end{array}$ & $\begin{array}{c}556-10 \\
\text { Hole } 556 \\
8-2 \\
13-16 \\
517.65 \\
18\end{array}$ & $\begin{array}{c}556-11 \\
\text { Hole } 556 \\
9-4 \\
64-67 \\
530.16 \\
1 A\end{array}$ & $\begin{array}{c}556-12 \\
\text { Hole } 556 \\
10-3 \\
63-66 \\
537.65 \\
1 B\end{array}$ & $\begin{array}{c}556-13 \\
\text { Hole } 556 \\
10-4 \\
72-75 \\
539.24 \\
\text { IA }\end{array}$ & $\begin{array}{c}556-14 \\
\text { Hole } 556 \\
11-2 \\
121-124 \\
545.73 \\
1 A\end{array}$ & $\begin{array}{c}556-15 \\
\text { Hole } 556 \\
12-3 \\
54-57 \\
555.56 \\
1 A\end{array}$ & $\begin{array}{c}556-16 \\
\text { Hole } 556 \\
12-4 \\
27-30 \\
556.78 \\
1 \mathrm{~A}\end{array}$ & $\begin{array}{c}556-17 \\
\text { Hole } 556 \\
16-2 \\
110-113 \\
586.1 \\
18\end{array}$ & $\begin{array}{c}557-1 \\
\text { Hole } 557 \\
1-1 \\
50-53 \\
461.02 \\
11\end{array}$ \\
\hline \multicolumn{19}{|l|}{ Major elements (wt.\%) } \\
\hline $\begin{array}{l}\mathrm{SiO}_{2} \\
\mathrm{TiO}_{2} \\
\mathrm{Al}_{2} \mathrm{O}_{3} \\
\mathrm{Fe}_{2} \mathrm{O}_{3} \\
\mathrm{MnO} \\
\mathrm{MgO} \\
\mathrm{CaO} \\
\mathrm{Na}_{2} \mathrm{O} \\
\mathrm{K}_{2} \mathrm{O} \\
\mathrm{P}_{2} \mathrm{O}_{5}\end{array}$ & $\begin{array}{r}50.55 \\
1.05 \\
15.63 \\
9.54 \\
0.15 \\
7.58 \\
12.52 \\
2.01 \\
0.35 \\
0.12\end{array}$ & $\begin{array}{r}50.22 \\
1.05 \\
15.96 \\
8.72 \\
0.15 \\
7.51 \\
13.31 \\
2.02 \\
0.20 \\
0.12\end{array}$ & $\begin{array}{r}50.04 \\
1.49 \\
16.05 \\
10.91 \\
0.17 \\
6.64 \\
11.72 \\
2.83 \\
0.31 \\
0.15\end{array}$ & $\begin{array}{r}50.03 \\
1.41 \\
15.46 \\
11.42 \\
0.18 \\
6.92 \\
11.74 \\
2.58 \\
0.37 \\
0.16\end{array}$ & $\begin{array}{r}50.21 \\
1.49 \\
15.97 \\
10.83 \\
0.17 \\
6.58 \\
11.57 \\
2.46 \\
0.27 \\
0.16\end{array}$ & $\begin{array}{r}50.69 \\
1.39 \\
16.33 \\
9.75 \\
0.17 \\
6.84 \\
11.80 \\
3.09 \\
0.14 \\
0.14\end{array}$ & $\begin{array}{r}49.50 \\
1.00 \\
16.28 \\
8.43 \\
0.15 \\
7.59 \\
14.39 \\
2.59 \\
0.24 \\
0.11\end{array}$ & $\begin{array}{r}50.12 \\
1.03 \\
15.89 \\
10.08 \\
0.16 \\
7.17 \\
12.74 \\
2.60 \\
0.29 \\
0.11\end{array}$ & $\begin{array}{r}50.02 \\
1.03 \\
16.11 \\
8.98 \\
0.17 \\
7.33 \\
13.36 \\
2.51 \\
0.35 \\
0.11\end{array}$ & $\begin{array}{r}50.37 \\
0.88 \\
15.85 \\
8.33 \\
0.14 \\
7.87 \\
14.25 \\
2.38 \\
0.27 \\
0.11\end{array}$ & $\begin{array}{r}50.85 \\
1.08 \\
15.38 \\
9.49 \\
0.15 \\
7.60 \\
12.57 \\
2.76 \\
0.33 \\
0.11\end{array}$ & $\begin{array}{r}49.71 \\
0.83 \\
17.79 \\
7.55 \\
0.12 \\
7.19 \\
14.16 \\
2.54 \\
0.25 \\
0.10\end{array}$ & $\begin{array}{r}50.26 \\
0.99 \\
16.38 \\
8.72 \\
0.15 \\
7.09 \\
13.53 \\
2.33 \\
0.38 \\
0.12\end{array}$ & $\begin{array}{r}50.41 \\
1.02 \\
15.49 \\
9.19 \\
0.16 \\
7.57 \\
13.38 \\
2.26 \\
0.38 \\
0.10\end{array}$ & $\begin{array}{r}50.33 \\
0.97 \\
16.28 \\
8.91 \\
0.14 \\
7.58 \\
12.90 \\
2.21 \\
0.33 \\
0.11\end{array}$ & $\begin{array}{r}50.46 \\
0.99 \\
16.00 \\
9.11 \\
0.15 \\
7.26 \\
12.88 \\
2.30 \\
0.53 \\
0.11\end{array}$ & $\begin{array}{r}50.10 \\
0.88 \\
15.64 \\
8.59 \\
0.16 \\
7.54 \\
14.27 \\
2.09 \\
0.24 \\
0.11\end{array}$ & $\begin{array}{r}47.87 \\
3.67 \\
12.73 \\
16.51 \\
0.22 \\
5.01 \\
10.00 \\
2.66 \\
0.52 \\
0.41\end{array}$ \\
\hline Total & 99.50 & 99.28 & 100.31 & 100.27 & 99.71 & 100.34 & 100.26 & 100.20 & 99.98 & 100.44 & 100.32 & 100.24 & 99.94 & 99.96 & 99.75 & 99.78 & 99.61 & 99.59 \\
\hline \multicolumn{19}{|l|}{ Trace elements (ppm) } \\
\hline $\begin{array}{l}\mathrm{Rb} \\
\mathrm{Sr} \\
\mathrm{Y} \\
\mathrm{Ga} \\
\mathrm{Zr} \\
\mathrm{Nb} \\
\mathrm{Zn} \\
\mathrm{Ni} \\
\mathrm{Cr} \\
\mathrm{V}\end{array}$ & $\begin{array}{c}7.1 \\
105 \\
23.4 \\
15.7 \\
62 \\
2.3 \\
77 \\
95 \\
311 \\
241\end{array}$ & $\begin{array}{c}2.4 \\
104 \\
23.9 \\
15.2 \\
64 \\
2.3 \\
75 \\
178 \\
277 \\
238\end{array}$ & $\begin{array}{c}5.5 \\
101 \\
32.7 \\
16.7 \\
97 \\
2.2 \\
92 \\
84 \\
235 \\
55\end{array}$ & $\begin{array}{c}7.1 \\
99 \\
30.7 \\
16.1 \\
89 \\
2.4 \\
84 \\
88 \\
251 \\
238\end{array}$ & $\begin{array}{c}4.3 \\
101 \\
33.1 \\
16.4 \\
87 \\
2.6 \\
87 \\
88 \\
251 \\
238\end{array}$ & $\begin{array}{c}1.8 \\
98 \\
30.7 \\
17.0 \\
88 \\
2.7 \\
97 \\
97 \\
280 \\
250\end{array}$ & $\begin{array}{c}2.3 \\
101 \\
22.6 \\
14.7 \\
56 \\
2.2 \\
73 \\
145 \\
366 \\
215\end{array}$ & $\begin{array}{c}6.3 \\
99 \\
22.2 \\
15.4 \\
58 \\
1.2 \\
68 \\
91 \\
331 \\
208\end{array}$ & $\begin{array}{c}4.1 \\
97 \\
23.3 \\
15.0 \\
56 \\
2.0 \\
74 \\
81 \\
373 \\
218\end{array}$ & $\begin{array}{c}3.2 \\
99 \\
20.4 \\
14.0 \\
48 \\
2.1 \\
68 \\
106 \\
284 \\
221\end{array}$ & $\begin{array}{r}10.7 \\
99.3 \\
24.3 \\
15.2 \\
60.4 \\
1.9 \\
80.1 \\
73.3 \\
93.8 \\
253.2\end{array}$ & $\begin{array}{r}3.8 \\
99.1 \\
18.2 \\
16.1 \\
46.4 \\
2.4 \\
76.1 \\
90.0 \\
381.2 \\
201.9\end{array}$ & $\begin{array}{r}10.7 \\
97.2 \\
21.5 \\
15.4 \\
58.1 \\
1.7 \\
77.3 \\
90.2 \\
404.6 \\
229.4\end{array}$ & $\begin{array}{r}9.4 \\
103.6 \\
23.0 \\
15.5 \\
56.0 \\
1.2 \\
69.0 \\
73.0 \\
239.6 \\
228.0\end{array}$ & $\begin{array}{r}5.7 \\
95.7 \\
21.8 \\
14.7 \\
55.6 \\
1.0 \\
71.0 \\
91.6 \\
387.7 \\
222.9\end{array}$ & $\begin{array}{r}14.4 \\
94.1 \\
21.3 \\
15.0 \\
58.2 \\
1.5 \\
65.4 \\
91.2 \\
395.4 \\
224.7\end{array}$ & $\begin{array}{r}2.8 \\
98.5 \\
20.1 \\
14.3 \\
50.4 \\
1.6 \\
69.4 \\
135.7 \\
291.6 \\
231.5\end{array}$ & $\begin{array}{r}10.8 \\
299.0 \\
41.0 \\
22.6 \\
216.2 \\
26.2 \\
113.3 \\
38.3 \\
18.7 \\
300.0\end{array}$ \\
\hline $\begin{array}{l}\mathrm{Mg}^{\prime} \text {-value } \\
\mathrm{FeO} \cdot \\
\mathrm{CaO} / \mathrm{Al}_{2} \mathrm{O}_{3} \\
\mathrm{Zr} / \mathrm{Nb} \\
\mathrm{Zr} / \mathrm{Y}\end{array}$ & $\begin{array}{c}0.64 \\
8.58 \\
0.80 \\
27.2 \\
2.67\end{array}$ & $\begin{array}{c}0.65 \\
7.85 \\
0.83 \\
27.7 \\
2.67\end{array}$ & $\begin{array}{c}0.57 \\
9.82 \\
0.73 \\
43.9 \\
2.96\end{array}$ & $\begin{array}{c}0.57 \\
10.28 \\
0.76 \\
37.0 \\
2.89\end{array}$ & $\begin{array}{c}0.57 \\
9.75 \\
0.72 \\
37.5 \\
2.95\end{array}$ & $\begin{array}{c}0.61 \\
8.77 \\
0.72 \\
32.6 \\
2.86\end{array}$ & $\begin{array}{c}0.66 \\
7.59 \\
0.88 \\
25.5 \\
2.49\end{array}$ & $\begin{array}{c}0.61 \\
9.07 \\
0.80 \\
48.4 \\
2.62\end{array}$ & $\begin{array}{c}0.64 \\
8.08 \\
0.83 \\
28.2 \\
2.42\end{array}$ & $\begin{array}{c}0.68 \\
7.50 \\
0.90 \\
23.1 \\
2.38\end{array}$ & $\begin{array}{c}0.64 \\
8.54 \\
0.82 \\
31.8 \\
2.49\end{array}$ & $\begin{array}{c}0.68 \\
6.79 \\
0.80 \\
19.3 \\
2.55\end{array}$ & $\begin{array}{c}0.64 \\
7.85 \\
0.83 \\
34.2 \\
2.70\end{array}$ & $\begin{array}{c}0.64 \\
8.27 \\
0.86 \\
46.7 \\
2.43\end{array}$ & $\begin{array}{c}0.65 \\
8.02 \\
0.79 \\
55.6 \\
2.55\end{array}$ & $\begin{array}{c}0.64 \\
8.20 \\
0.81 \\
38.8 \\
2.73\end{array}$ & $\begin{array}{c}0.66 \\
7.73 \\
0.91 \\
31.5 \\
2.51\end{array}$ & $\begin{array}{c}0.40 \\
14.86 \\
0.61 \\
8.3 \\
5.27\end{array}$ \\
\hline
\end{tabular}

Note: See note at beginning of Appendix A. 
Table 2. Hole 558.

\begin{tabular}{|c|c|c|c|c|c|c|c|c|c|c|c|c|c|c|c|c|}
\hline $\begin{array}{l}\text { Univ. Mass, sample no. } \\
\text { Core-Section }\end{array}$ & $\begin{array}{c}558-1 \\
27-3\end{array}$ & $\begin{array}{l}558-2 \\
28-1\end{array}$ & $\begin{array}{c}558-3 \\
30-1\end{array}$ & $\begin{array}{c}558-4 \\
32-2\end{array}$ & $\begin{array}{l}558-5 \\
32-4\end{array}$ & $\begin{array}{l}558-6 \\
32-5\end{array}$ & $\begin{array}{r}558-7 \\
33-2\end{array}$ & $\begin{array}{c}558-8 \\
33-3\end{array}$ & $\begin{array}{c}558-9 \\
33-3\end{array}$ & $\begin{array}{c}558-10 \\
35-3\end{array}$ & $\begin{array}{c}558-11 \\
36-1\end{array}$ & $\begin{array}{c}558-12 \\
37-1\end{array}$ & $\begin{array}{c}558-13 \\
38-1\end{array}$ & $\begin{array}{c}558-14 \\
38-2\end{array}$ & $\begin{array}{c}558-15 \\
39-1\end{array}$ & $\begin{array}{c}558-16 \\
39-2\end{array}$ \\
\hline (interval in $\mathrm{cm}$ ) & $112-114$ & $55-58$ & $115-118$ & $130-132$ & $73-75$ & $101-103$ & $144-147$ & $61-64$ & $139-14 \mid$ & $107-109$ & $74-78$ & $89-92$ & $97-99$ & $116-118$ & $111-113$ & $11-13$ \\
\hline Sub-bottom depth $(\mathrm{m})$ & 409.13 & 415.07 & 433.67 & 453.31 & 455.74 & 457.51 & 462.46 & 463.13 & 463.90 & 481.58 & 487.26 & 496.41 & 505.48 & 507.17 & 510.12 & 510.62 \\
\hline Chemical group & IA & II & IIIA & IIIB & IIIB & IIIB & IIIB & IIIB & IIIB & IA & IB & IV & IV & IV & IV & IV \\
\hline \multicolumn{17}{|l|}{ Major elements (wt.\%) } \\
\hline $\mathrm{SiO}_{2}$ & 50.60 & 51.09 & 50.32 & 50.33 & 50.42 & 49.94 & 50.38 & 50.29 & 49.93 & 49.43 & 49.22 & 49.35 & 49.12 & 49.45 & 48.89 & 49.61 \\
\hline $\mathrm{TiO}_{2}$ & 1.25 & 1.16 & 1.45 & 1.35 & 1.30 & 1.30 & 1.31 & 1.30 & 1.31 & 1.22 & 1.31 & 0.98 & 0.95 & 0.99 & 1.02 & 0.96 \\
\hline $\mathrm{Al}_{2} \mathrm{O}_{3}$ & 14.64 & 15.82 & 15.16 & 15.40 & 14.86 & 15.30 & 14.85 & 14.92 & 15.34 & 15.03 & 15.54 & 16.15 & 15.70 & 16.15 & 16.61 & 15.60 \\
\hline $\mathrm{Fe}_{2} \mathrm{O}_{3} \mathrm{-}$ & 10.32 & 8.80 & 10.46 & 9.36 & 9.83 & 9.91 & 9.83 & 9.86 & 9.72 & 10.14 & 10.43 & 9.90 & 9.87 & 10.10 & 10.48 & 9.87 \\
\hline $\mathrm{MnO}$ & 0.15 & 0.16 & 0.15 & 0.14 & 0.17 & 0.14 & 0.17 & 0.16 & 0.15 & 0.17 & 0.18 & 0.14 & 0.17 & 0.16 & 0.17 & 0.18 \\
\hline $\mathrm{MgO}$ & 9.53 & 8.26 & 8.17 & 8.67 & 8.97 & 8.78 & 9.01 & 9.05 & 8.70 & 8.92 & 7.82 & 8.33 & 10.80 & 8.33 & 7.54 & 9.89 \\
\hline $\mathrm{CaO}$ & 10.62 & 12.40 & 11.58 & 11.89 & 11.63 & 11.70 & 11.55 & 11.51 & 11.74 & 12.13 & 12.26 & 12.04 & 11.71 & 12.21 & 12.92 & 11.71 \\
\hline $\mathrm{Na}_{2} \mathrm{O}$ & 2.21 & 2.15 & 2.30 & 2.24 & 2.13 & 2.35 & 1.84 & 1.88 & 2.36 & 2.52 & 2.28 & 2.16 & 2.09 & 2.12 & 2.32 & 2.17 \\
\hline $\mathrm{K}_{2} \mathrm{O}$ & 0.26 & 0.17 & 0.46 & 0.40 & 0.31 & 0.41 & 0.30 & 0.30 & 0.38 & 0.35 & 0.41 & 0.29 & 0.22 & 0.23 & 0.30 & 0.29 \\
\hline $\mathrm{P}_{2} \mathrm{O}_{5}$ & 0.15 & 0.12 & 0.21 & 0.19 & 0.17 & 0.19 & 0.18 & 0.18 & 0.18 & 0.16 & 0.20 & 0.14 & 0.13 & 0.13 & 0.14 & 0.13 \\
\hline Total & 99.72 & 100.14 & 100.27 & 99.97 & 99.80 & 100.04 & 99.40 & 99.45 & 99.81 & 100.06 & 99.63 & 99.48 & 100.76 & 99.87 & 100.38 & 100.40 \\
\hline \multicolumn{17}{|l|}{ Trace elements (ppm) } \\
\hline $\mathbf{R b}$ & 3.6 & 2.5 & 9.7 & 2.5 & 6.6 & 6.8 & 5.4 & 6.8 & 6.9 & 6 & 7.7 & 7 & 3.7 & 3.9 & 4.9 & 5 \\
\hline Sr & 128.9 & 94.7 & 170 & 179.5 & 174.8 & 176.4 & 174.5 & 173 & 175.2 & 142.2 & 145.9 & 111.2 & 108.2 & 114.1 & 116.2 & 109.1 \\
\hline Y & 22.2 & 25.6 & 24.2 & 21.8 & 21.6 & 21.2 & 21.8 & 21.1 & 21.2 & 22.5 & 24 & 18.5 & 18.5 & 19.2 & 19.2 & 18.2 \\
\hline Ga & 15.7 & 16 & 15.6 & 15.1 & 15.4 & 14 & 15.4 & 14.8 & 16.2 & 14.8 & 15.3 & 14.7 & 15.2 & 14.3 & 15.4 & 14.3 \\
\hline $\mathrm{Zr}$ & 75.87 & 66.53 & 92.80 & 84.62 & 82.60 & 81.50 & 82.19 & 82.79 & 80.24 & 75.99 & 85.64 & 55.40 & 54.76 & 57.29 & 57.86 & 55.74 \\
\hline $\mathrm{Nb}$ & 8.64 & 3.10 & 15.25 & 13.75 & 14.49 & 13.39 & 13.41 & 13.98 & 12.65 & 9.53 & 11.34 & 7.57 & 7.24 & 7.75 & 7.74 & 7.44 \\
\hline $\mathrm{Zn}$ & 83 & 90.33 & 89.45 & 85.61 & 83.87 & 81.33 & 87.74 & 98.53 & 84.74 & 87.02 & 87.44 & 78.63 & 73.14 & 82.6 & 88.65 & 72.26 \\
\hline $\mathrm{Ni}$ & 277.4 & 169.8 & 157.5 & 170.6 & 156.2 & 157.9 & 156.1 & 155.9 & 175.0 & 185.8 & 152.5 & 208.3 & 230.1 & 219.6 & 184.88 & 213.6 \\
\hline $\mathrm{Cr}$ & 509.7 & 400.5 & 356.3 & 367.0 & 388.9 & 371.6 & 384.8 & 398.3 & 362.8 & 380.5 & 308.5 & 458.4 & 449.4 & 481.5 & 476.6 & 441.5 \\
\hline v & 195.6 & 238.3 & 257.9 & 242.8 & 249.8 & 233.9 & 243.7 & 252.0 & 233.4 & 239.9 & 246.4 & 197.6 & 190.5 & 211.5 & 224.4 & 191.6 \\
\hline $\mathrm{Mg}^{\prime}$-value & 0.67 & 0.67 & 0.63 & 0.67 & 0.67 & 0.66 & 0.67 & 0.67 & 0.66 & 0.66 & 0.62 & 0.65 & 0.71 & 0.65 & 0.62 & 0.69 \\
\hline $\mathrm{FeO}^{*}$ & 9.29 & 7.92 & 9.41 & 8.42 & 8.85 & 8.92 & 8.85 & 8.87 & 8.75 & 9.12 & 9.39 & 8.90 & 8.88 & 9.09 & 9.43 & 8.88 \\
\hline $\mathrm{CaO} / \mathrm{Al}_{2} \mathrm{O}_{3}$ & 0.73 & 0.78 & 0.76 & 0.77 & 0.78 & 0.76 & 0.78 & 0.77 & 0.77 & 0.81 & 0.79 & 0.75 & 0.75 & 0.76 & 0.78 & 0.75 \\
\hline $\mathrm{Zr} / \mathrm{Nb}$ & 8.78 & 21.46 & 6.09 & 6.15 & 5.70 & 6.09 & 6.13 & 5.92 & 6.34 & 7.97 & 7.55 & 7.32 & 7.56 & 7.39 & 7.48 & 7.49 \\
\hline $\mathrm{Zr} / \mathrm{Y}$ & 3.42 & 2.60 & 3.83 & 3.88 & 3.82 & 3.84 & 3.77 & 3.92 & 3.78 & 3.38 & 3.57 & 2.99 & 2.96 & 2.98 & 3.01 & 3.06 \\
\hline
\end{tabular}

Note: See note at beginning of Appendix A.

Table 3. Hole 559.

\begin{tabular}{|c|c|c|c|c|c|c|c|c|c|}
\hline $\begin{array}{l}\text { Univ. Mass. sample no. } \\
\text { Core-Section } \\
\text { (interval in } \mathrm{cm} \text { ) } \\
\text { Sub-bottom depth (m) }\end{array}$ & $\begin{array}{c}559-1 \\
1-1 \\
117-119 \\
239-18\end{array}$ & $\begin{array}{c}559-2 \\
2-3 \\
111-113 \\
251.12\end{array}$ & $\begin{array}{c}559-3 \\
4-1 \\
121-124 \\
257.72\end{array}$ & $\begin{array}{c}559-4 \\
5-1 \\
50-53 \\
265.51\end{array}$ & $\begin{array}{c}559-5 \\
6-2 \\
14-16 \\
275.65\end{array}$ & $\begin{array}{c}559-6 \\
7-1 \\
111-114 \\
284.12\end{array}$ & $\begin{array}{c}559-7 \\
7-3 \\
18-20 \\
286.19\end{array}$ & $\begin{array}{c}559-8 \\
7-3 \\
103-106 \\
287.19\end{array}$ & $\begin{array}{c}559-9 \\
8-3 \\
6-10 \\
295.08\end{array}$ \\
\hline \multicolumn{10}{|l|}{ Major elements (wt.\%) } \\
\hline $\begin{array}{l}\mathrm{SiO}_{2} \\
\mathrm{TiO}_{2} \\
\mathrm{Al}_{2} \mathrm{O}_{3} \\
\mathrm{Fe}_{2} \mathrm{O}_{3} \\
\mathrm{MnO} \\
\mathrm{MgO} \\
\mathrm{CaO} \\
\mathrm{Na}_{2} \mathrm{O} \\
\mathrm{K}_{2} \mathrm{O} \\
\mathrm{P}_{2} \mathrm{O}_{5}\end{array}$ & $\begin{array}{r}49.23 \\
1.61 \\
16.19 \\
11.30 \\
0.17 \\
6.45 \\
11.73 \\
2.76 \\
0.62 \\
0.25\end{array}$ & $\begin{array}{r}50.62 \\
1.52 \\
15.49 \\
9.93 \\
0.12 \\
7.84 \\
11.57 \\
2.70 \\
0.35 \\
0.20\end{array}$ & $\begin{array}{r}49.90 \\
1.54 \\
15.35 \\
10.44 \\
0.16 \\
7.56 \\
11.78 \\
2.64 \\
0.38 \\
0.21\end{array}$ & $\begin{array}{r}49.50 \\
1.54 \\
15.40 \\
11.21 \\
0.19 \\
6.69 \\
11.94 \\
2.77 \\
0.44 \\
0.21\end{array}$ & $\begin{array}{r}49.67 \\
1.54 \\
15.39 \\
10.59 \\
0.15 \\
7.28 \\
11.69 \\
2.39 \\
0.44 \\
0.20\end{array}$ & $\begin{array}{r}48.48 \\
1.59 \\
15.86 \\
11.71 \\
0.19 \\
6.38 \\
12.35 \\
2.47 \\
0.42 \\
0.24\end{array}$ & $\begin{array}{r}49.68 \\
1.54 \\
15.31 \\
10.77 \\
0.15 \\
7.46 \\
11.35 \\
2.54 \\
0.51 \\
0.20\end{array}$ & $\begin{array}{r}49.97 \\
1.52 \\
14.97 \\
10.80 \\
0.16 \\
7.52 \\
11.24 \\
2.59 \\
0.39 \\
0.21\end{array}$ & $\begin{array}{r}48.65 \\
1.50 \\
15.14 \\
12.02 \\
0.24 \\
6.77 \\
11.98 \\
2.33 \\
0.69 \\
0.20\end{array}$ \\
\hline Total & 100.30 & 100.34 & 99.96 & 99.89 & 99.35 & 99.69 & 99.51 & 99.38 & 99.52 \\
\hline \multicolumn{10}{|l|}{ Trace elements (ppm) } \\
\hline $\begin{array}{l}\mathrm{Rb} \\
\mathrm{Sr} \\
\mathrm{Y} \\
\mathrm{Ga} \\
\mathrm{Zr} \\
\mathrm{Nb} \\
\mathrm{Zn} \\
\mathrm{Ni} \\
\mathrm{Cr} \\
\mathrm{V}\end{array}$ & $\begin{array}{r}9.9 \\
167.9 \\
31.6 \\
13.3 \\
108.4 \\
15.5 \\
176.0 \\
103.9 \\
163.8 \\
291.9\end{array}$ & $\begin{array}{r}5.9 \\
162.5 \\
27.1 \\
15.7 \\
105.4 \\
14.4 \\
90.4 \\
211.2 \\
254.7 \\
246.5\end{array}$ & $\begin{array}{r}5.2 \\
162.8 \\
28.3 \\
15.8 \\
107.0 \\
15.0 \\
98.3 \\
142.0 \\
267.3 \\
266.8\end{array}$ & $\begin{array}{r}6.5 \\
166.6 \\
28.0 \\
16.0 \\
105.7 \\
15.2 \\
102.7 \\
126.9 \\
260.9 \\
276.9\end{array}$ & $\begin{array}{r}7.4 \\
161.8 \\
27.8 \\
17.2 \\
107.5 \\
14.7 \\
91.0 \\
127.3 \\
277.1 \\
267.1\end{array}$ & $\begin{array}{r}6.9 \\
171.4 \\
29.2 \\
16.9 \\
111.6 \\
15.6 \\
96.6 \\
113.2 \\
276.1 \\
291.9\end{array}$ & $\begin{array}{r}7.0 \\
161.8 \\
28.2 \\
16.5 \\
106.8 \\
15.4 \\
96.5 \\
121.0 \\
247.3 \\
253.8\end{array}$ & $\begin{array}{r}7.0 \\
161.1 \\
27.6 \\
15.7 \\
107.0 \\
15.0 \\
88.3 \\
108.9 \\
245.5 \\
252.7\end{array}$ & $\begin{array}{r}17.0 \\
169.0 \\
27.1 \\
17.2 \\
103.1 \\
14.5 \\
83.6 \\
134.4 \\
253.6 \\
253.6\end{array}$ \\
\hline $\mathrm{Mg}^{\prime}$-value & 0.56 & 0.63 & 0.61 & 0.57 & 0.60 & 0.55 & 0.60 & 0.61 & 0.55 \\
\hline $\begin{array}{l}\mathrm{FeO} * \\
\mathrm{CaO} / \mathrm{Al}_{2} \mathrm{O}_{3} \\
\mathrm{Zr} / \mathrm{Nb} \\
\mathrm{Zr} / \mathrm{Y}\end{array}$ & $\begin{array}{r}10.17 \\
0.72 \\
6.99 \\
3.43\end{array}$ & $\begin{array}{l}8.94 \\
0.75 \\
7.32 \\
3.89\end{array}$ & $\begin{array}{l}9.39 \\
0.77 \\
7.13 \\
3.78\end{array}$ & $\begin{array}{r}10.09 \\
0.78 \\
6.95 \\
3.78\end{array}$ & $\begin{array}{l}9.53 \\
0.76 \\
7.31 \\
3.87\end{array}$ & $\begin{array}{r}10.54 \\
0.78 \\
7.15 \\
3.82\end{array}$ & $\begin{array}{l}9.69 \\
0.74 \\
6.94 \\
3.79\end{array}$ & $\begin{array}{l}9.72 \\
0.75 \\
7.13 \\
3.88\end{array}$ & $\begin{array}{r}10.82 \\
0.79 \\
7.11 \\
3.80\end{array}$ \\
\hline
\end{tabular}

Note: See note at beginning of Appendix A. All samples belong to Chemical Group I. 
Table 4. Hole 561.

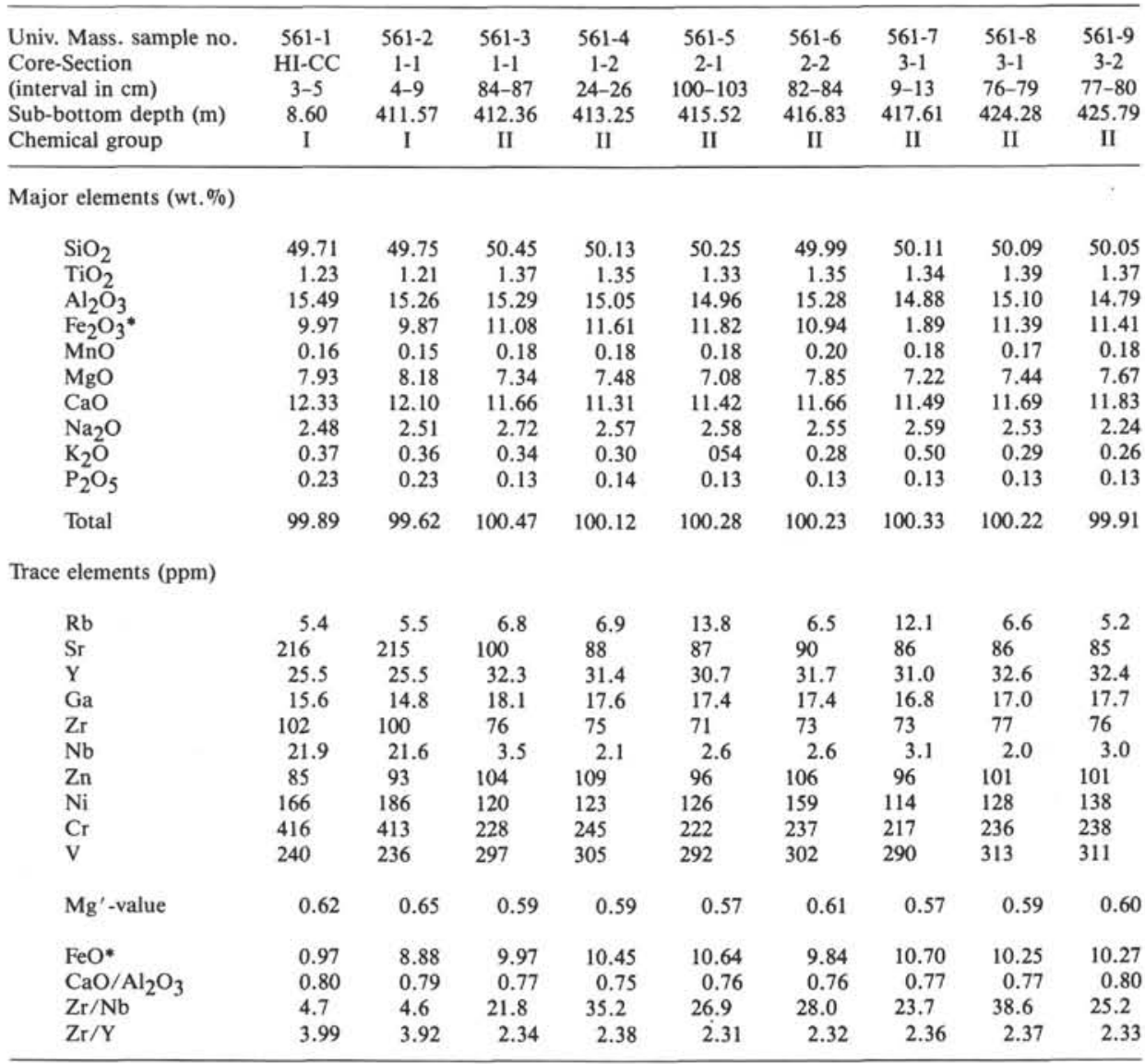

Note: See note at beginning of Appendix A.

Table 5. Hole 562.

\begin{tabular}{|c|c|c|c|c|c|c|c|c|c|c|c|c|c|c|c|c|}
\hline $\begin{array}{l}\text { Univ. Mass. sample no. } \\
\text { Core-Section }\end{array}$ & $\begin{array}{c}562-1 \\
\mathrm{H} 1-\mathrm{CC}\end{array}$ & $\begin{array}{c}562-2 \\
2-3\end{array}$ & $\begin{array}{c}562-3 \\
4-1\end{array}$ & $\begin{array}{c}562-4 \\
5-1\end{array}$ & $\begin{array}{c}562-5 \\
5-4\end{array}$ & $\begin{array}{c}562-6 \\
6-3\end{array}$ & $\begin{array}{c}562-7 \\
6-4\end{array}$ & $\begin{array}{c}562-8 \\
7-2\end{array}$ & $\begin{array}{c}562-9 \\
8-1\end{array}$ & $\begin{array}{c}562-10 \\
8-1\end{array}$ & $\begin{array}{c}562-11 \\
8-2\end{array}$ & $\begin{array}{c}562-12 \\
9-1\end{array}$ & $\begin{array}{c}562-13 \\
9-1\end{array}$ & $\begin{array}{c}562-14 \\
10-1\end{array}$ & $\begin{array}{l}562-15 \\
10-3\end{array}$ & $\begin{array}{c}562-16 \\
11-1\end{array}$ \\
\hline (interval in $\mathrm{cm}$ ) & $16-19$ & $8-10$ & $75-77$ & $64-66$ & $29-31$ & $135-138$ & $6-10$ & $56-58$ & $132-134$ & $144-146$ & $25-29$ & $82-84$ & $145-147$ & $90-93$ & $52-55$ & $115-117$ \\
\hline Sub-bottom depth (m) & 243.23 & 253.09 & 268.76 & 277.65 & 281.80 & 290.37 & 290.58 & 297.07 & 301.33 & 301.45 & 306.77 & 304,77 & 305.46 & 313.92 & 316.54 & 323.16 \\
\hline Chemical group & 1 & 1 & 1 & 1 & I & 1 & I & 1 & I & I & II & II & II & II & II & II \\
\hline \multicolumn{17}{|l|}{ Major elements (wt. \%) } \\
\hline $\mathrm{SiO}_{2}$ & 49.23 & 49.91 & 49.83 & 50.32 & 49.52 & 49.32 & 50.19 & 49.98 & 49.67 & 49.43 & 48.90 & 48.33 & 49.78 & 49.12 & 49.72 & 49.18 \\
\hline $\mathrm{TiO}_{2}$ & 1.57 & 1.58 & 1.60 & 1.58 & 1.54 & 1.54 & 1.20 & 1.20 & 1.25 & 1.30 & 1.16 & 1.19 & 1.28 & 1.26 & 1.29 & 1.15 \\
\hline $\mathrm{Al}_{2} \mathrm{O}_{3}$ & 15.71 & 15.31 & 15.21 & 15.97 & 15.82 & 15.69 & 17.27 & 16.22 & 16.38 & 15.50 & 17.11 & 16.73 & 15.75 & 16.01 & 15.38 & 17.43 \\
\hline $\mathrm{Fe}_{2} \mathrm{O}_{3} \cdot$ & 11.90 & 11.79 & 11.75 & 10.70 & 11.25 & 11.54 & 8.95 & 10.34 & 9.89 & 10.17 & 9.91 & 9.89 & 10.57 & 11.07 & 10.60 & 9.81 \\
\hline $\mathrm{MnO}$ & 0.18 & 0.18 & 0.19 & 0.16 & 0.17 & 0.20 & 0.13 & 0.16 & 0.16 & 0.17 & 0.15 & 0.18 & 0.17 & 0.18 & 0.17 & 0.16 \\
\hline $\mathrm{MgO}$ & 6.71 & 7.24 & 7.41 & 6.73 & 7.05 & 7.03 & 6.94 & 7.19 & 7.28 & 7.61 & 7.37 & 7.28 & 7.16 & 7.09 & 7.82 & 6.52 \\
\hline $\mathrm{CaO}$ & 11.64 & 11.53 & 11.42 & 11.85 & 11.53 & 11.84 & 12.90 & 12.31 & 12.63 & 13.23 & 12.97 & 13.85 & 12.44 & 12.96 & 12.45 & 12.92 \\
\hline $\mathrm{Na}_{2} \mathrm{O}$ & 2.29 & 2.42 & 2.55 & 2.52 & 2.70 & 2.63 & 2.14 & 2.01 & 2.17 & 2.20 & 1.97 & 2.04 & 2.04 & 2.1 & 2.02 & 1.91 \\
\hline $\mathrm{K}_{2} \mathrm{O}$ & 0.25 & 0.31 & 0.13 & 0.21 & 0.10 & 0.35 & 0.18 & 0.22 & 0.21 & 0.25 & 0.21 & 0.22 & 0.38 & 0.32 & 0.26 & 0.25 \\
\hline $\mathrm{P}_{2} \mathrm{O}_{5}$ & 0.15 & 0.14 & 0.17 & 0.16 & 0.15 & 0.16 & 0.13 & 0.12 & 0.13 & 0.13 & 0.13 & 0.13 & 0.14 & 0.14 & 0.13 & 0.12 \\
\hline Total & 99.63 & 100.41 & 100.26 & 100.19 & 99.83 & 100.30 & 100.02 & 99.75 & 99.79 & 99.98 & 99.88 & 99.84 & 99.69 & 100.24 & 99.84 & 99.46 \\
\hline \multicolumn{17}{|l|}{ Trace elements (ppm) } \\
\hline $\mathrm{Rb}$ & 2.6 & 5.6 & 1.9 & 2.3 & 1.2 & 6.7 & 3.1 & 3.5 & 3.9 & 4.5 & 3.3 & 4.1 & 8.2 & 6.1 & 4.6 & 4.7 \\
\hline $\mathrm{Sr}$ & 105 & 96.6 & 94.4 & 99.5 & 102.1 & 103.6 & 91.9 & 97.5 & 96.4 & 108.4 & 90.4 & 101.3 & 114.4 & 95.1 & 89.6 & 94.5 \\
\hline $\mathbf{Y}$ & 36.1 & 35.1 & 35 & 34.9 & 34.4 & 32.9 & 26.5 & 26.3 & 27.7 & 29.4 & 25.1 & 26 & 28.7 & 28 & 28.5 & 25.2 \\
\hline Ga & 17.5 & 17.3 & 17.8 & 17.3 & 17.1 & 17.9 & 16.1 & 16.3 & 16.5 & 16.1 & 15.5 & 16.1 & 16.9 & 16.6 & 16.5 & 15.9 \\
\hline $\mathrm{Zr}$ & 96.5 & 97.3 & 92.4 & 96.4 & 93.4 & 93 & 69 & 67.5 & 72.1 & 74.3 & 65.7 & 67.8 & 73.4 & 73.3 & 74 & 65 \\
\hline $\mathrm{Nb}$ & 3.1 & 3.9 & 3.8 & 3.4 & 3.2 & 3.1 & 2.5 & 2.2 & 2.7 & 2.5 & 2.3 & 3.0 & 2.3 & 2.7 & 2.5 & 2.8 \\
\hline $\mathrm{Zn}$ & 103.9 & 95.6 & 90.1 & 95.8 & 86.6 & 106.2 & 83 & 80.1 & 88.1 & 93.1 & 81.2 & 83.6 & 93.9 & 99.3 & 95.2 & 81.1 \\
\hline $\mathrm{Ni}$ & 109.2 & 107.6 & 106 & 119.5 & 105.1 & 109.2 & 169.5 & 105.7 & 102 & 121.6 & 98.7 & 109.6 & 112.5 & 104.2 & 124.4 & 98.2 \\
\hline $\mathrm{Cr}$ & 241.8 & 236.5 & 211.1 & 235.4 & 215.3 & 246.6 & 244.9 & 242.8 & 262 & 267.8 & 248.6 & 251.2 & 265.1 & 264.2 & 268.1 & 250.6 \\
\hline $\mathrm{v}$ & 313.8 & 298.9 & 284.1 & 286.7 & 274 & 286.1 & 250 & 243.3 & 267 & 278.4 & 243.4 & 254.6 & 282.7 & 277.3 & 279.9 & 244.2 \\
\hline $\mathrm{Mg}^{\prime}$-value & 0.55 & 0.57 & 0.58 & 0.58 & 0.58 & 0.57 & 0.63 & 0.60 & 0.62 & 0.62 & 0.62 & 0.62 & 0.60 & 0.58 & 0.62 & 0.59 \\
\hline $\mathrm{FeO}^{*}$ & 10.71 & 10.61 & 10.57 & 9.63 & 10.12 & 10.38 & 8.05 & 9.30 & 8.90 & 9.15 & 8.92 & 8.90 & 9.51 & 9.96 & 9.54 & 8.83 \\
\hline $\mathrm{CaO} / \mathrm{Al}_{2} \mathrm{O}_{3}$ & 0.74 & 0.75 & 0.75 & 0.74 & 0.73 & 0.75 & 0.75 & 0.76 & 0.77 & 0.85 & 0.76 & 0.83 & 0.79 & 0.81 & 0.81 & 0.74 \\
\hline $\mathrm{Zr} / \mathrm{Nb}$ & 31.1 & 24.9 & 25.6 & 28.4 & 29.2 & 30.0 & 27.6 & 30.7 & 26.7 & 29.7 & 28.6 & 22.6 & 31.9 & 27.1 & 29.6 & 23.2 \\
\hline $\mathrm{Z}_{\mathrm{r}} / \mathrm{Y}$ & 2.67 & 2.77 & 2.78 & 2.76 & 2.72 & 2.83 & 2.60 & 2.55 & 2.60 & 2.53 & 2.62 & 2.61 & 2.56 & 2.62 & 2.60 & 2.58 \\
\hline
\end{tabular}

Note: See note at beginning of Appendix A. 
Table 6. Hole 563.

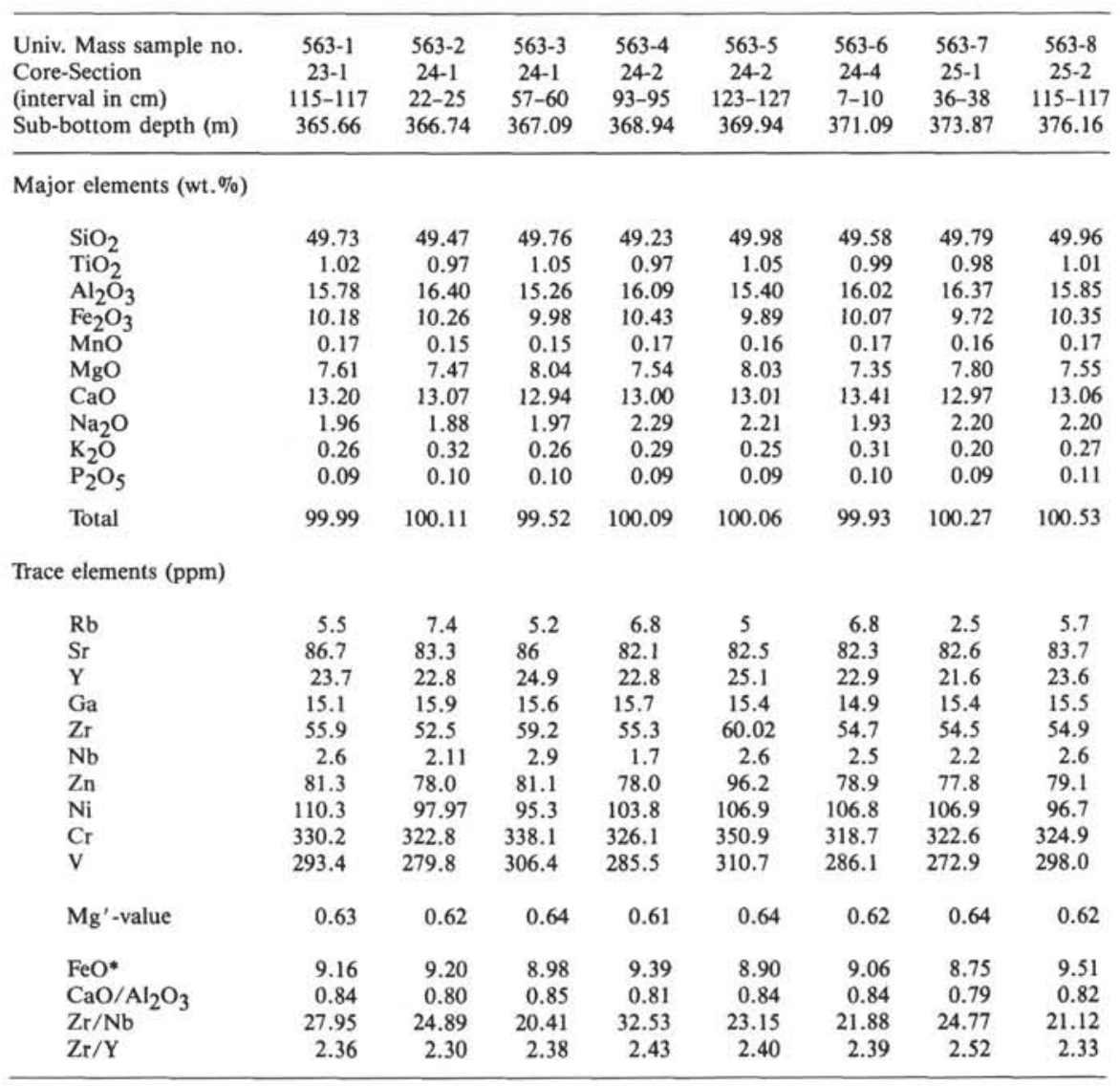

Note: See note at beginning of Appendix A. All samples belong to Chemical Group I.

Table 7. Hole 564.

\begin{tabular}{|c|c|c|c|c|c|c|c|c|c|c|c|c|c|c|c|c|c|c|c|c|}
\hline $\begin{array}{l}\text { Univ Mass, sample no. } \\
\text { Core-Section } \\
\text { (interval in } \mathrm{cm} \text { ) } \\
\text { Sub-bottom depth (m) }\end{array}$ & $\begin{array}{l}364-1 \\
\text { H1-CC } \\
11-15 \\
282.61\end{array}$ & $\begin{array}{c}564-2 \\
1-1 \\
129-131 \\
285.30\end{array}$ & $\begin{array}{c}564-3 \\
1-3 \\
38-40 \\
287,39\end{array}$ & $\begin{array}{c}564-4 \\
2-2 \\
3-5 \\
294.54\end{array}$ & $\begin{array}{l}564.5 \\
2.3 \\
18-20 \\
296.19\end{array}$ & $\begin{array}{c}564-6 \\
3.2 \\
35-37 \\
303,86\end{array}$ & $\begin{array}{c}564.7 \\
4-2 \\
37-4 ! \\
312.89\end{array}$ & $\begin{array}{c}564-8 \\
4-4 \\
140-142 \\
316.91\end{array}$ & $\begin{array}{l}564-9 \\
5-2 \\
89-91 \\
322,40\end{array}$ & $\begin{array}{l}564-10 \\
5-4 \\
24-27 \\
324.76\end{array}$ & $\begin{array}{c}564-11 \\
6-1 \\
15-18 \\
329.17\end{array}$ & $\begin{array}{c}564-12 \\
64 \\
48-52 \\
334.00\end{array}$ & $\begin{array}{c}564-13 \\
6-5 \\
32-34 \\
335.33\end{array}$ & $\begin{array}{c}564-14 \\
7-1 \\
12-15 \\
338.14\end{array}$ & $\begin{array}{c}564-15 \\
7-3 \\
13-15 \\
341.14\end{array}$ & $\begin{array}{c}564-16 \\
8 \cdot 2 \\
7-10 \\
348.59\end{array}$ & $\begin{array}{c}564-17 \\
9-1 \\
18-20 \\
356.19\end{array}$ & $\begin{array}{c}564-18 \\
9-1 \\
140-143 \\
357.42\end{array}$ & $\begin{array}{c}564-19 \\
9-2 \\
128-130 \\
358.79\end{array}$ & $\begin{array}{c}564-20 \\
9-3 \\
68-71 \\
359.70\end{array}$ \\
\hline \multicolumn{21}{|l|}{ Major elements (wr.\%) } \\
\hline $\mathrm{SiO}_{2}$ & 49.35 & 50.21 & 49.86 & 49.57 & 50.58 & 49.62 & 49.87 & 49.88 & 50.39 & 49.44 & 50.54 & 49.42 & 50.17 & 49.77 & 50.63 & 49.87 & 47.24 & 49.11 & 48.99 & 49.34 \\
\hline $\mathrm{TOO}_{2}$ & 1.48 & 1.43 & 1.40 & 1.44 & 1.47 & 1.45 & 1.46 & 1.45 & 1.46 & 1.51 & 1.48 & 1.44 & 1.50 & 1.49 & 1.52 & 1.48 & 1.52 & 1.53 & 1.58 & 1.55 \\
\hline $\mathrm{Al}_{2} \mathrm{O}_{3}$. & 15.77 & 14.94 & 14.71 & 15.22 & 15.17 & 14.92 & 14.89 & 14.76 & 14.69 & 14.99 & 14.64 & 14.38 & 14.64 & 14.5 & 14.73 & 14.56 & 15.16 & 15.08 & 15.04 & $\begin{array}{l}14.96 \\
12.56\end{array}$ \\
\hline $\begin{array}{l}\mathrm{Fe}_{2}{ }_{2} \mathrm{O}_{3} \\
\mathrm{MnO}^{\circ}\end{array}$ & $\begin{array}{r}11.55 \\
0.19\end{array}$ & $\begin{array}{r}11.29 \\
0.18\end{array}$ & $\begin{array}{r}11.58 \\
0.17\end{array}$ & $\begin{array}{r}11.60 \\
0.18\end{array}$ & $\begin{array}{r}10.11 \\
0.17\end{array}$ & $\begin{array}{r}11.71 \\
0.20\end{array}$ & $\begin{array}{r}11.92 \\
0.20\end{array}$ & $\begin{array}{r}11.82 \\
0.16\end{array}$ & $\begin{array}{r}11.82 \\
0.17\end{array}$ & $\begin{array}{r}12.37 \\
0.19\end{array}$ & $\begin{array}{r}11.86 \\
0.17\end{array}$ & $\begin{array}{r}12.31 \\
0.19\end{array}$ & $\begin{array}{r}11.95 \\
0.18\end{array}$ & $\begin{array}{r}11.96 \\
0.17\end{array}$ & $\begin{array}{r}11.56 \\
0.18\end{array}$ & $\begin{array}{r}11.90 \\
0.17\end{array}$ & $\begin{array}{r}13.07 \\
0.19\end{array}$ & $\begin{array}{r}12.01 \\
0.18\end{array}$ & $\begin{array}{r}12.53 \\
0.18\end{array}$ & $\begin{array}{r}12.56 \\
0.20\end{array}$ \\
\hline $\mathrm{MgO}_{8}$ & 6.13 & 7.52 & 7.59 & 7.00 & 7.77 & 7.32 & 7.32 & 7.54 & 7.48 & 6.78 & 7.24 & 8.43 & 7.48 & 7.42 & 6.99 & 7.54 & 5.20 & $\begin{array}{l}0.18 \\
6.86\end{array}$ & $\begin{array}{l}0.18 \\
6.70\end{array}$ & $\begin{array}{l}0.20 \\
6.81\end{array}$ \\
\hline $\mathrm{CaO}$ & 12.82 & 11.89 & 11.63 & 12.15 & 12.05 & 11.92 & 11.76 & 11.52 & 11.52 & 11.76 & 11.42 & 11.28 & 11.53 & 11.45 & 11.67 & 11.40 & 13.83 & 11.76 & 11.86 & 11.87 \\
\hline $\mathrm{Na}_{2} \mathrm{O}$ & 2.51 & 2.47 & 2.76 & 2.39 & 2.26 & 2.82 & 2.31 & 2.56 & 2.48 & 2.58 & 2.12 & 2.05 & 2.08 & 2.10 & 2.15 & 2.22 & 2.26 & 2.66 & 2.28 & 2.44 \\
\hline $\mathrm{K}_{2} \mathrm{O}$ & 0.44 & 0.35 & 0.36 & 0.39 & 0.20 & 0.38 & 0.36 & 0.36 & 0.19 & 0.40 & 0.19 & 0.24 & 0.33 & 0.41 & 0.23 & 0.42 & 0.62 & 0.36 & 0.35 & 0.33 \\
\hline $\mathrm{P}_{2} \mathrm{O}_{5}$ & 0.16 & 0.14 & 0.15 & 0.16 & 0.15 & 0.14 & 0.15 & 0.17 & 0.16 & 0.17 & 0.16 & 0.16 & 0.17 & 0.16 & 0.16 & 0.16 & 0.21 & 0.17 & 0.17 & 0.17 \\
\hline Total & 100.40 & 100.42 & 100.22 & 100.10 & 99.93 & 100.47 & 100.26 & 100.22 & 100.34 & 100.19 & 99.83 & 99.92 & 100.03 & 99.42 & 99.82 & 99.73 & 99.31 & 99.73 & 99.67 & 100.23 \\
\hline \multicolumn{21}{|l|}{ Trace elements (ppm) } \\
\hline$R b$ & 7.5 & 6.4 & 6.0 & 5.8 & 2.7 & 6.3 & 5.8 & 7.2 & 2.6 & 7.0 & 2.3 & 4.9 & .7 & 7.2 & 2.6 & 7.5 & 14.7 & 9 & 5.2 & 6.3 \\
\hline Sr & 115.1 & 106.8 & 101.8 & 103.6 & 108.1 & 105.5 & 103.0 & 99.9 & 99.5 & 105.6 & 100.9 & 104.8 & 101.2 & 103.6 & 102.1 & 103.2 & 114.6 & 106.9 & 107.9 & 107.2 \\
\hline$Y$ & 31.7 & 32.2 & 31.8 & 32.3 & 33.7 & 32.8 & 32.5 & 32.2 & 32.7 & 33.6 & 33.4 & 31.9 & 33.0 & 33.3 & 34.2 & 32.5 & 35.6 & 33.4 & 34.1 & 33.8 \\
\hline $\mathrm{Ga}$ & 17.4 & 16.1 & 16.4 & 17.2 & 18.0 & 17.2 & 16.6 & 16.4 & 17.2 & 17. & 16.6 & 16.4 & 17.0 & 17.2 & 17.1 & 16.2 & 19.3 & 17.7 & 17.1 & 17.4 \\
\hline $\mathrm{Zr}$ & 93.7 & 91.3 & 90.9 & 92,4 & 94.3 & 95.4 & 92.8 & 92.9 & 95.5 & 98.1 & 94.6 & 93.6 & 96.6 & 97.3 & 99.1 & 97.4 & 96.1 & 98.9 & 100.5 & 101.3 \\
\hline $\mathrm{Nb}$ & 4.1 & 3.9 & 4.4 & 4.7 & 3.9 & 5.0 & 4.6 & 4.9 & 4.2 & 5.2 & 5.4 & 4.5 & 4.9 & 5.2 & 5.6 & 5.5 & 5.8 & 60 & 5.7 & 6.7 \\
\hline $\mathrm{Zn}$ & 101.3 & 95.3 & 94.2 & 101,4 & 98.1 & 110.1 & 95.2 & 98.2 & 107.5 & 102.1 & 91.8 & 92.2 & 94.3 & 98.4 & 96.7 & 97.6 & 85.3 & 111.2 & 109.7 & 107.3 \\
\hline$N$ & 122.7 & 138.5 & 112.8 & 121.1 & 154.4 & 104.5 & 104.1 & 117.8 & 117.5 & 113.7 & 118.6 & 144.2 & 123 & 119.8 & 121.0 & 118.6 & 103 & 139.7 & 121.2 & 117.3 \\
\hline $\mathrm{Cr}$ & 277,4 & 261.5 & 258.2 & 258.3 & 242.0 & & & & 238.6 & 240.9 & 221.4 & 214.1 & 222.3 & 236.2 & 235.3 & 232.3 & 217.2 & 222.8 & 215.1 & 233.7 \\
\hline v & 352.0 & 346.6 & 339.1 & 348.9 & 339.1 & 349.2 & 340.8 & 338.4 & 339.1 & 360.2 & 335.2 & 325.9 & 340.2 & 349.4 & 346.7 & 346.0 & 383.7 & 362.1 & 371.3 & 365.3 \\
\hline $\mathrm{Mg}$ 'value $^{-}$ & 0.54 & 0.59 & 0.59 & 0.57 & 0.63 & 0.58 & 0.58 & 0.58 & 0.58 & 0.55 & 0.57 & 0.60 & 0.58 & 0.58 & 0.57 & 0.58 & 0.47 & 0.56 & 0.54 & 0.54 \\
\hline For & 10. & 10 & 10 & 10 & 9 & 10 & 10 & 10 & 11 & 10. & 10. & 11 & 10. & 10. & 10. & 10. & 11.76 & 10.8 & 11.28 & 11.30 \\
\hline$D_{3}$ & 0.81 & 0.80 & 0.79 & 0. & 0.79 & 0.80 & 0.79 & 0.78 & 0.78 & 0.78 & 0.78 & 0.78 & 0.79 & 0.79 & 0.79 & 0.78 & 0.91 & 0.78 & 0.79 & 0.79 \\
\hline $\mathrm{Zr} / \mathrm{Nb}$ & 22.9 & 23.4 & 20.7 & 19.7 & 24.2 & 19.1 & 20.2 & 19.0 & 22.7 & 18.9 & 17.5 & 20.8 & 19.7 & 18.7 & 17.7 & 17.7 & 16.6 & 16.5 & 17.6 & 15.1 \\
\hline $\mathrm{Zr} / \mathrm{Y}$ & 2.96 & 2.83 & 2.86 & 2.86 & 2.80 & 2.91 & 2.86 & 2.88 & 2.92 & 2.92 & 2.83 & 2.93 & 2.93 & 2.92 & 2.90 & 3.00 & 2,70 & 2.96 & 2.95 & 3.00 \\
\hline
\end{tabular}

Note: See note at beginning of Appendix A. All samples belong to Chemical Group I. 


\section{APPENDIX B}

Average Compositions of Basalts from Leg 82

Note to Appendix B tables: $\mathrm{N}$ refers to number of samples in each chemical group. $\mathrm{Fe}_{2} \mathrm{O}_{3}{ }^{*}$ and $\mathrm{FeO}^{*}$ refer to total $\mathrm{Fe}$ expressed as $\mathrm{Fe}^{3+}$ or $\mathrm{Fe}^{2+}$ Calculation of $\mathrm{Mg}^{\prime}$-value is discussed in the text $\left(\mathrm{Mg} /\left[\mathrm{Mg}+\mathrm{Fe}^{2}\right]\right)$. Small discrepancies in totals may be attributed to rounding.

Table 1. Hole 556.

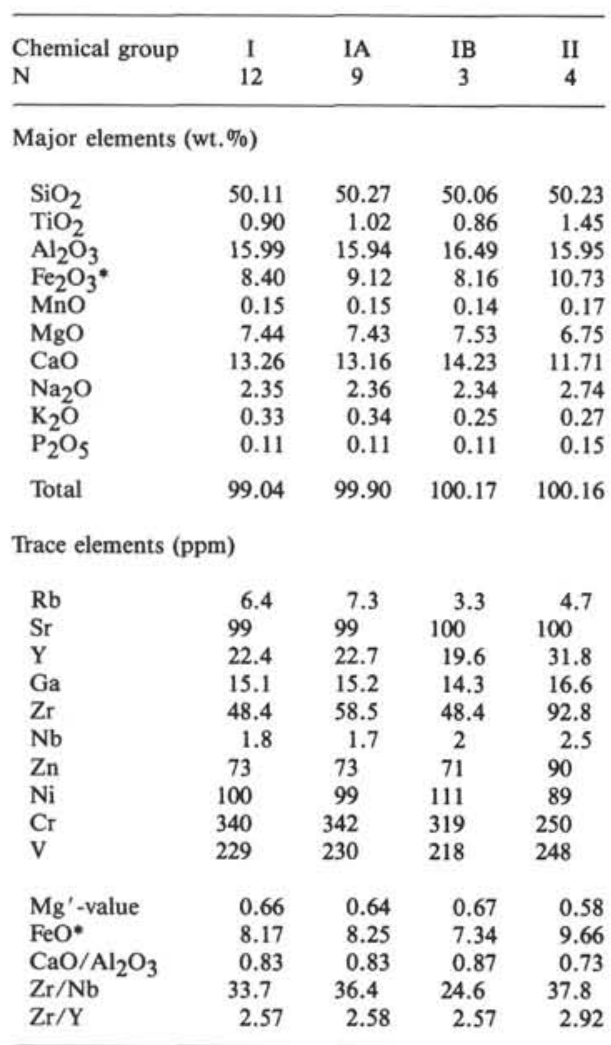

Note: See note at beginning of Appendix B.
Table 2. Hole 558.

\begin{tabular}{|c|c|c|c|c|c|c|}
\hline $\begin{array}{l}\text { Chemical group } \\
\mathrm{N}\end{array}$ & $\begin{array}{l}1 \\
3\end{array}$ & $\begin{array}{l}\text { II } \\
1\end{array}$ & $\begin{array}{c}\text { III } \\
7\end{array}$ & $\underset{1}{\mathrm{IIIA}}$ & $\underset{6}{\mathrm{IIIB}}$ & $\begin{array}{c}\text { IV } \\
5\end{array}$ \\
\hline \multicolumn{7}{|c|}{ Major elements (wt.\%) } \\
\hline $\mathrm{SiO}_{2}$ & 49.75 & 51.09 & 50.27 & 50.32 & 50.22 & 49.28 \\
\hline $\mathrm{TiO}_{2}$ & 1.26 & 1.16 & 1.35 & 1.45 & 1.31 & 0.99 \\
\hline $\mathrm{Al}_{2} \mathrm{O}_{3}$ & 15.07 & 15.82 & 15.14 & 15.16 & 15.11 & 16.05 \\
\hline $\mathrm{Fe}_{2} \mathrm{O}_{3}{ }^{*}$ & 10.30 & 8.80 & 10.11 & 10.46 & 9.75 & 10.06 \\
\hline $\mathrm{MnO}^{3}$ & 0.17 & 0.16 & 0.16 & 0.15 & 0.16 & 0.16 \\
\hline $\mathrm{MgO}$ & 8.76 & 8.26 & 8.52 & 8.17 & 8.86 & 8.90 \\
\hline $\mathrm{CaO}$ & 11.67 & 12.40 & 11.63 & 11.58 & 11.67 & 12.11 \\
\hline $\mathrm{Na}_{2} \mathrm{O}$ & 2.34 & 2.15 & 2.22 & 2.30 & 2.13 & 2.12 \\
\hline $\mathrm{K}_{2} \mathrm{O}$ & 0.36 & 0.17 & 0.41 & 0.46 & 0.35 & 0.26 \\
\hline $\mathrm{P}_{2} \mathrm{O}_{5}$ & 0.17 & 0.12 & 0.20 & 0.21 & 0.18 & 0.13 \\
\hline Total & 99.85 & 100.14 & 100.01 & 100.27 & 99.75 & 100.06 \\
\hline
\end{tabular}

Trace elements (ppm)

\begin{tabular}{lcccccc}
$\mathrm{Rb}$ & 5.8 & 2.5 & 8.20 & 9.7 & 6.7 & 4.9 \\
$\mathrm{Sr}$ & 139 & 95 & 173 & 170 & 176 & 112 \\
$\mathrm{Y}$ & 22.9 & 25.6 & 22.8 & 24.2 & 21.45 & 18.7 \\
$\mathrm{Ga}$ & 15.3 & 16.0 & 15.4 & 15.6 & 15.2 & 14.8 \\
$\mathrm{Zr}$ & 79.2 & 66.5 & 87.6 & 92.8 & 82.3 & 56.2 \\
$\mathrm{Nb}$ & 9.8 & 3.1 & 14.4 & 15.2 & 13.6 & 7.5 \\
$\mathrm{Zn}$ & 87.2 & 90 & 88 & 89 & 87 & 79 \\
$\mathrm{Ni}$ & 169 & 170 & 160 & 157 & 162 & 205 \\
$\mathrm{Cr}$ & 344 & 400 & 368 & 356 & 379 & 461 \\
$\mathrm{~V}$ & 243 & 238 & 250 & 259 & 243 & 203 \\
& & & & & & \\
$\mathrm{Mg}$-value & 0.65 & 0.68 & 0.66 & 0.64 & 0.67 & 0.66 \\
$\mathrm{FeO}$ & 9.27 & 7.92 & 9.10 & 9.41 & 8.79 & 9.05 \\
$\mathrm{CaO} / \mathrm{Al}_{2} \mathrm{O}_{3}$ & 0.78 & 0.78 & 0.77 & 0.77 & 0.77 & 0.76 \\
$\mathrm{Zr} / \mathrm{Nb}^{2}$ & 8.10 & 21.46 & 6.08 & 6.09 & 6.06 & 7.45 \\
$\mathrm{Zr} / \mathrm{Y}$ & 3.46 & 2.60 & 3.83 & 3.83 & 3.83 & 3.00 \\
\hline
\end{tabular}

Note: See note at beginning of Appendix B. 
Table 3. Hole 559.

\begin{tabular}{lr}
\hline $\begin{array}{l}\text { Chemical group } \\
\mathrm{N}\end{array}$ & \multicolumn{1}{c}{1} \\
\hline \multicolumn{2}{l}{ Major elements (wt. \%) } \\
\multicolumn{2}{c}{} \\
$\mathrm{SiO}_{2}$ & 49.52 \\
$\mathrm{TiO}_{2}$ & 1.54 \\
$\mathrm{Al}_{2} \mathrm{O}_{2}$ & 15.46 \\
$\mathrm{Fe}_{2} \mathrm{O}_{3}{ }^{*}$ & 10.97 \\
$\mathrm{MnO}$ & 0.17 \\
$\mathrm{MgO}$ & 7.11 \\
$\mathrm{CaO}$ & 11.73 \\
$\mathrm{Na}_{2} \mathrm{O}$ & 2.58 \\
$\mathrm{~K}_{2} \mathrm{O}$ & 0.47 \\
$\mathrm{P}_{2} \mathrm{O}_{5}$ & 0.21 \\
Total & 99.77
\end{tabular}

Trace elements (ppm)

\begin{tabular}{lc}
$\mathrm{Rb}$ & 8.1 \\
$\mathrm{Sr}$ & 165 \\
$\mathrm{Y}$ & 28.3 \\
$\mathrm{Ga}$ & 16.0 \\
$\mathrm{Zr}$ & 106.9 \\
$\mathrm{Nb}$ & 15.0 \\
$\mathrm{Zn}$ & 103 \\
$\mathrm{Ni}$ & 135 \\
$\mathrm{Cr}$ & 258 \\
$\mathrm{~V}$ & 267 \\
& \\
$\mathrm{Mg}^{\prime}$-value & 0.59 \\
$\mathrm{FeO}$ & 9.88 \\
$\mathrm{CaO} / \mathrm{Al}_{2} \mathrm{O}_{3}$ & 0.76 \\
$\mathrm{Zr} / \mathrm{Nb}$ & 7.09 \\
$\mathrm{Zr} / \mathrm{Y}$ & 3.78 \\
\hline
\end{tabular}

Note: See note at beginning of Appendix B.
Table 4. Hole 561.

\begin{tabular}{lrr}
\hline $\begin{array}{l}\text { Chemical group } \\
\mathrm{N}\end{array}$ & \multicolumn{1}{c}{$\mathrm{I}$} & \multicolumn{1}{c}{$\mathrm{II}$} \\
& \multicolumn{1}{c}{7} \\
\hline \multicolumn{2}{l}{ Major elements (wt.\%) } \\
& \\
$\mathrm{SiO}_{2}$ & 49.73 & 50.15 \\
$\mathrm{TiO}_{2}$ & 1.22 & 1.36 \\
$\mathrm{Al}_{2} \mathrm{O}_{3}$ & 15.38 & 14.99 \\
$\mathrm{Fe}_{2} \mathrm{O}_{3}^{*}$ & 9.92 & 11.45 \\
$\mathrm{MnO}$ & 0.16 & 0.18 \\
$\mathrm{MgO}$ & 8.06 & 7.44 \\
$\mathrm{CaO}$ & 12.21 & 11.58 \\
$\mathrm{Na} 2$ & 2.50 & 2.54 \\
$\mathrm{~K}_{2} \mathrm{O}$ & 0.36 & 0.36 \\
$\mathrm{P}_{2} \mathrm{O}_{5}$ & 0.23 & 0.13 \\
Total & 99.75 & 100.18 \\
& &
\end{tabular}

Trace elements (ppm)

\begin{tabular}{lcc}
$\mathrm{Rb}$ & 5.5 & 8.3 \\
$\mathrm{Sr}$ & 215 & 89 \\
$\mathrm{Y}$ & 25.5 & 31.7 \\
$\mathrm{Ga}$ & 15.2 & 17.4 \\
$\mathrm{Zr}$ & 100.9 & 74.4 \\
$\mathrm{Nb}$ & 21.7 & 2.7 \\
$\mathrm{Zn}$ & 69 & 102 \\
$\mathrm{Ni}$ & 176 & 130 \\
$\mathrm{Cr}$ & 414 & 232 \\
$\mathrm{~V}$ & 238 & 301 \\
& & \\
$\mathrm{Mg}^{\prime}$-value & 0.64 & 0.59 \\
$\mathrm{FeO}{ }^{*}$ & 8.92 & 10.30 \\
$\mathrm{CaO} / \mathrm{Al}_{2} \mathrm{O}_{3}$ & 0.80 & 0.77 \\
$\mathrm{Zr} / \mathrm{Nb}$ & 4.65 & 28.5 \\
$\mathrm{Zr} / \mathrm{Y}$ & 3.95 & 2.34 \\
\hline
\end{tabular}

Note: See note at beginning of Appendix $\mathrm{B}$.
Table 5. Hole 562.

\begin{tabular}{|c|c|c|}
\hline $\begin{array}{l}\text { Chemical group } \\
\mathrm{N}\end{array}$ & $\begin{array}{l}\text { I } \\
6\end{array}$ & $\begin{array}{l}\text { II } \\
10\end{array}$ \\
\hline \multicolumn{3}{|c|}{ Major elements (wt.\%) } \\
\hline $\mathrm{SiO}_{2}$ & 49.69 & 49.43 \\
\hline $\mathrm{TiO}_{2}$ & 1.57 & 1.23 \\
\hline $\mathrm{Al}_{2} \mathrm{O}_{3}$ & 15.59 & 16.38 \\
\hline $\mathrm{Fe}_{2} \mathrm{O}_{3}^{*}$ & 11.49 & 10.21 \\
\hline $\mathrm{MnO}$ & 0.18 & 0.16 \\
\hline $\mathrm{MgO}$ & 7.03 & 7.23 \\
\hline $\mathrm{CaO}$ & 11.64 & 12.87 \\
\hline $\mathrm{Na}_{2} \mathrm{O}$ & 2.52 & 2.06 \\
\hline $\mathrm{K}_{2} \mathrm{O}$ & 0.23 & 0.25 \\
\hline $\mathrm{P}_{2} \mathrm{O}_{5}$ & 0.16 & 0.13 \\
\hline Total & 100.10 & 99.95 \\
\hline
\end{tabular}

Trace elements (ppm)

\begin{tabular}{lcc}
$\mathrm{Rb}$ & 3.9 & 4.6 \\
$\mathrm{Sr}$ & 100 & 98 \\
$\mathrm{Y}$ & 34.2 & 27.1 \\
$\mathrm{Ga}$ & 17.5 & 16.2 \\
$\mathrm{Zr}$ & 95.7 & 70.2 \\
$\mathrm{Nb}$ & 3.4 & 2.6 \\
$\mathrm{Zn}$ & 96 & 88 \\
$\mathrm{Ni}$ & 109 & 108 \\
$\mathrm{Cr}$ & 231 & 256 \\
$\mathrm{~V}$ & 291 & 262 \\
& & \\
$\mathrm{Mg}^{\prime}$-value & 0.57 & 0.61 \\
$\mathrm{FeO}$ & 10.34 & 9.11 \\
$\mathrm{CaO} / \mathrm{Al}_{2} \mathrm{O}_{3}$ & 0.74 & 0.79 \\
$\mathrm{Zr} / \mathrm{Nb}$ & 28.2 & 27.8 \\
$\mathrm{Zr} / \mathrm{Y}$ & 2.76 & 2.59 \\
\hline
\end{tabular}

Note: See note at beginning of Appendix B.
Table 6. Hole 563.

\begin{tabular}{|c|c|}
\hline $\begin{array}{l}\text { Chemical group } \\
\mathrm{N}\end{array}$ & $\begin{array}{l}1 \\
8\end{array}$ \\
\hline \multicolumn{2}{|c|}{ Major elements (wt.\%) } \\
\hline $\mathrm{SiO}_{2}$ & 49.69 \\
\hline $\mathrm{TiO}_{2}^{2}$ & 1.00 \\
\hline $\mathrm{Al}_{2} \mathrm{O}_{3}$ & 15.90 \\
\hline $\mathrm{Fe}_{2} \mathrm{O}_{3}{ }^{*}$ & 10.11 \\
\hline $\mathrm{MnO}^{\circ}$ & 0.16 \\
\hline $\mathrm{MgO}$ & 7.67 \\
\hline $\mathrm{CaO}$ & 13.08 \\
\hline $\mathrm{Na}_{2} \mathrm{O}$ & 2.08 \\
\hline $\mathrm{K}_{2} \mathrm{O}$ & 0.27 \\
\hline $\mathrm{P}_{2} \mathrm{O}_{5}$ & 0.10 \\
\hline Total & 100.06 \\
\hline
\end{tabular}

Trace elements (ppm)

\begin{tabular}{lc}
$\mathrm{Rb}$ & 5.6 \\
$\mathrm{Sr}$ & 84 \\
$\mathrm{Y}$ & 23.4 \\
$\mathrm{Ga}$ & 15.4 \\
$\mathrm{Zr}$ & 55.9 \\
$\mathrm{Nb}$ & 2.3 \\
$\mathrm{Zn}$ & 81 \\
$\mathrm{Ni}$ & 103 \\
$\mathrm{Cr}$ & 329 \\
$\mathrm{~V}$ & 292 \\
$\mathrm{Mg}{ }^{\prime}-\mathrm{value}^{2}$ & 0.63 \\
$\mathrm{FeO}$ & 9.16 \\
$\mathrm{CaO} / \mathrm{Al}_{2} \mathrm{O}_{3}$ & 0.82 \\
$\mathrm{Zr} / \mathrm{Nb}^{2}$ & 24.6 \\
$\mathrm{Zr} / \mathrm{Y}$ & 2.39 \\
\hline
\end{tabular}

Note: See note at beginning of Appendix B.
Table 7. Hole 564.

\begin{tabular}{l} 
Chemical group I \\
$\mathrm{N}$ \\
\hline Major elements (wt. \%)
\end{tabular}

$\begin{array}{lr}\mathrm{SiO}_{2} & 49.69 \\ \mathrm{TiO}_{2} & 1.48 \\ \mathrm{Al}_{2} \mathrm{O}_{3} & 14.89 \\ \mathrm{Fe}_{2} \mathrm{O}_{3} & 11.87 \\ \mathrm{MnO} & 0.18 \\ \mathrm{MgO} & 7.16 \\ \mathrm{CaO} & 11.85 \\ \mathrm{Na} 2 & 2.38 \\ \mathrm{~K}_{2} \mathrm{O} & 0.35 \\ \mathrm{P}_{2} \mathrm{O}_{5} & 0.16 \\ \text { Total } & 100.01\end{array}$

Trace elements (ppm)

\begin{tabular}{lc}
$\mathrm{Rb}$ & 6.1 \\
$\mathrm{Sr}$ & 105 \\
$\mathrm{Y}$ & 33.0 \\
$\mathrm{Ga}$ & 17.1 \\
$\mathrm{Zr}$ & 95.6 \\
$\mathrm{Nb}$ & 5.0 \\
$\mathrm{Zn}$ & 99 \\
$\mathrm{Ni}$ & 117 \\
$\mathrm{Cr}$ & 238 \\
$\mathrm{~V}$ & 349 \\
& \\
$\mathrm{Mg}^{\prime}$-value & 0.57 \\
$\mathrm{FeO}$ & 10.69 \\
$\mathrm{CaO} / \mathrm{Al}_{2} \mathrm{O}_{3}$ & 0.80 \\
$\mathrm{Zr} / \mathrm{Nb}$ & 19.4 \\
$\mathrm{Zr} / \mathrm{Y}$ & 2.90 \\
\hline
\end{tabular}

Note: See note at beginning of Appendix B. 